This is the peer reviewed version of the following article: How Information Technology Assimilation Promotes Exploratory and Exploitative Innovation in the Small- and Medium-Sized Firm Context: The Role of Contextual Ambidexterity and Knowledge Base, which has been published in final form at https://doi.org/10.1111/jpim.12486. This article may be used for non-commercial purposes in accordance with Wiley Terms and Conditions for Self-Archiving.

\title{
How Information Technology Assimilation promotes Exploratory and Exploitative Innovation in the Small- and Medium-Sized Firm Context: The Role of Contextual Ambidexterity and Knowledge Base
}

\begin{abstract}
This research sheds new light on how information technology (IT) assimilation affects exploratory and exploitative innovation in the context of small- and medium-sized firms (SMEs). This contextualization is important in establishing the boundary conditions for the theory, as well as generating specific managerial insights for SME managers. A sample of 248 UK-based SMEs in the manufacturing industry demonstrates contextual ambidexterity (CA) mediates the relationship between IT assimilation and two types of innovation. This finding highlights that IT assimilation does not automatically promote innovation. Instead, IT assimilation represents a critical resource that enables the effective implementation of CA, which in turn affects innovation. This implies that SMEs cannot fully realize the potential of their IT assimilation and use it to enable innovation without implementing CA. Furthermore, this study differentiates between two different dimensions of knowledge base: knowledge breadth and knowledge depth. This study finds that knowledge breadth moderates the indirect IT assimilation-exploratory innovation relationship by influencing the effect of $\mathrm{CA}$ on exploratory innovation. Knowledge depth, on the other hand, moderates the indirect IT assimilation-exploitative innovation relationship by influencing the effect of $\mathrm{CA}$ on exploitative innovation. This finding implies that SMEs can benefit from their IT assimilation that enables them to engage in CA, which in turn allows them to perform innovation. However, it is apparent that the dimension of knowledge that SMEs hold internally can determine what types of innovation that they are able to perform.
\end{abstract}

Keywords: Contextual Ambidexterity; Exploratory Innovation; Exploitative Innovation; Knowledge Base; Information Technology Assimilation, Small- and Medium-Sized Firms

\section{Practitioner Points:}

- SME managers should focus their efforts not only on applying IT effectively in their business operations but also on enabling CA, which creates a more favorable internal environment for innovation to flourish.

- SME managers who wish to capitalize on their IT assimilation and CA to promote exploratory innovation should invest in the development of a broad knowledge base (diverse knowledge in multiple domains - knowledge breadth).

- SME managers who wish to capitalize on their IT assimilation and CA to promote exploitative innovation should invest in the development of a deep knowledge base (in-depth knowledge in a specific field - knowledge depth). 


\section{INTRODUCTION}

Innovation refers to the applications of new knowledge, ideas, methods and skills that allow firms to seize business opportunities and shape the competitive landscape (Zhou and $\mathrm{Li}$, 2012). The adoption of information technology (IT) to support innovation has emerged as a popular approach for managers to secure their firms' competitive positions in the marketplace. For example, an industry study shows that a high percentage (over 90\%) of senior executives believe that IT can be used to facilitate innovation (O'Mahony et al., 2003). According to the resource-based theory (RBT) perspective of IT, IT (assets) ${ }^{1}$ existing in a synergistic relationship with different business activities can lead to the development of "IT competency" (Liu et al., 2016; Nevo and Wade, 2010). A firm's IT competency allows it to perform value-creating activities which are the key drivers of superior performance (Nevo and Wade, 2010; Pavlou and El Sawy, 2010). Several researchers contend that innovation is one of the value-creating activities that can be enabled by firms' IT competency (e.g. SotoAcosta et al., 2018; Tarafdar and Gordon, 2007), but fail to specify the shape of such a relationship. Against this background, this study addresses three related research gaps with links to this IT competency-innovation relationship.

First, according to the RBT perspective of IT, the business value of IT competency lies in enabling other firm-level capabilities, which in turn allows firms to perform valuecreating activities effectively (Kohli and Grover, 2008; Ravichandran and Lertwongsatien, 2005). Applying this to this study's context, the RBT perspective of IT suggests that a firmlevel capability is a critical intervening variable to explain how IT competency may enable a value-creating activity such as innovation. However, the theory does not specify the types of firm-level capabilities that may act as mediators in such a relationship. Contextual ambidexterity (CA) refers to firms' ability to pursue alignment and adaptability goals concurrently ${ }^{2}$. In this research, this study proposes CA as a mediator of the relationship 
between IT competency and innovation, based on three reasons. Foremost, CA is acknowledged as a type of firm-level capability (De Clercq et al., 2013). Furthermore, researchers suggest that a firm's IT competency allows it to perform multiple tasks simultaneously (Dewett and Jones, 2001; Ravichandran and Lertwongsatien, 2005). Considering that the implementation of $\mathrm{CA}$ requires a firm to engage two separate, nonsubstitutable activities concurrently, a second reason arises. Lastly, previous research has already established a link between IT competency and CA (e.g. Im and Rai, 2013), as well as a connection between CA and innovation (e.g. Kortmann, 2015). Thus, this study concludes that CA is likely to be a mediator in the relationship between IT competency and innovation. However, no studies have examined the mediating role of CA in IT competency-innovation relationship.

Second, stemming from the RBT perspective of IT, researchers suggest that, since IT competency plays a critical role in firms' competitiveness, to realize the full potential of their IT competency, firms may require the complement of other important contingency factors (Radhakrishnan et al., 2008; Wade and Hulland, 2004). Building implicitly on this theoretical insight, previous studies recognize that the knowledge that firms have obtained externally can interact with their IT competency to enable innovation (e.g. Cui et al., 2015; Rai et al., 2012). In comparison, scholars know little about the role of firms' internal knowledge as a contingency factor to complement firms' IT competency in promoting innovation.

With this contention in mind, this study proposes that knowledge base may be a contingency factor for an indirect relationship between IT competency and innovation, thereby complementing the role of CA. This study examines firms' knowledge base for three reasons. Foremost, knowledge base refers to the knowledge assets that a firm has accumulated over time and holds internally (De Luca and Atuahene-Gima, 2007; Kale and Singh, 2007). Next, knowledge base captures the structure and content of firms' existing 
knowledge (Zhou and Li, 2012). Last but not least, knowledge base determines the firm's ability to capitalize on its ambidextrous postures and perform value-creating activities to achieve superior performance (De Clercq et al., 2014). This study differentiates two dimensions of knowledge base and examines their roles as contingency factors. Knowledge breadth refers to "the extent to which the organization's knowledge repository contains distinct and multiple domains", while knowledge depth describes "the level of sophistication and complexity of knowledge in key fields" (Zhou and Li, 2012: 1091). This distinction is important because the innovative ideas generated from combining knowledge within these two dimensions of knowledge base differ greatly (De Luca and Atuahene-Gima, 2007; Zahra and George, 2002), which may affect the effective leveraging of CA to support innovation differently. Still, this viewpoint remains unexplored.

Third, previous research often investigates the IT competency-innovation relationship in a general context (e.g. Tarafdar and Gordon, 2007), while few studies specifically adopt the perspective of small- and medium-sized firms (SMEs). Although it may be possible to transfer these findings to some degree to the SME context, SMEs with limited resources will have different priorities and challenges when embracing IT and implement innovation (Limaj et al., 2016; Soto-Acosta et al., 2018).

\section{"Insert Figure 1 about Here"}

To address these knowledge gaps, this study develops a framework (see Figure 1) to examine the indirect relationship between IT assimilation and two types of innovation (exploratory/exploitative innovation) through $\mathrm{CA}$, as well as the contingency effect of knowledge base on this indirect relationship. IT assimilation ${ }^{3}$ refers to a firm's capacity to apply IT to support, shape and enable its business activities (Armstrong and Sambamurthy, 1999; Liu et al., 2016). According to the RBT perspective of IT, IT assimilation is a form of IT competency that is valuable and difficult to replicate (Liu et al., 2016; Wade and Hulland, 
2004). This study investigates this form of IT competency because the adoption and integration of IT into business operations have become more central to SMEs' efforts to improve their efficiency, effectiveness and flexibility (Levy and Powell, 2000), and IT assimilation reflects this strategic focus (Armstrong and Sambamurthy, 1999).

This study focuses on two types of innovation. Exploratory innovation refers to the development and commercialization of products or services that are new to the market, whereas exploitative innovation refers to pushing advances in processes and technologies to improve the existing product and service offers (Kollmann and Stöckmann, 2014). Prior studies tend to investigate the impact of IT competency on either exploratory innovation (e.g Cui et al., 2015) or exploitative innovation (e.g. Banker et al., 2006). Few studies assess the impact of IT competency on both types of innovation in a single study (e.g. Limaj et al., 2016; Soto-Acosta et al., 2018). This study includes both types of innovation in the model to offer a more comprehensive view of how IT competency promotes innovation ${ }^{4}$. Furthermore, both types of innovation are highly relevant to this study's context. The engagement of exploratory innovation allows SMEs to address their customers' unmet needs and avoid directly competing with more resourceful rivals on similar product lines (Limaj et al., 2016). When SMEs are able to perform exploitative innovation, they are more likely to meet their customers' needs through cost reduction, production advancement, etc. (Prajogo and McDermott, 2014).

This study tests a framework using data collected from 248 UK-based SMEs in the manufacturing industry. This study aims to make three important contributions to the extant literature. Firstly, the prior literature explored the direct relationship between IT competency and innovation (Soto-Acosta et al., 2018; Tarafdar and Gordon, 2007). This study adds to existing knowledge by proposing that $\mathrm{CA}$ is a mediator that connects IT competency and innovation. This suggests that IT assimilation as SMEs' IT competency does not 
automatically promote innovation. Instead, it represents a critical resource that enables the effective implementation of CA, which in turn affects innovation.

Secondly, the prior literature has emphasized the role of knowledge that firms have obtained externally in affecting the relationship between IT competency and innovation (e.g. Cui et al., 2015; Rai et al., 2012). This study extends this literature by examining firms' internal knowledge (i.e. knowledge base) in complementing the role of CA in the indirect IT competency (IT assimilation)-innovation relationship. This represents an initial effort to assess the differential effects of knowledge breadth and knowledge depth (the two dimensions of knowledge base) on different types of innovation (exploratory/exploitative innovation) through their complementary relationship with CA. This suggests that the indirect IT assimilation-exploratory innovation relationship and IT assimilation-exploitative innovation relationship are contingent on different dimensions of the knowledge base.

Finally, this study extends the studies of the IT competency-innovation relationship in the SME context (Limaj et al., 2016; Soto-Acosta et al., 2018). This study builds and tests a framework from the SME perspective. This contextualization of the IT competencyinnovation relationship setting is important in establishing the boundary conditions for the theory, as well as generating specific managerial insights for SME managers. Overall, by investigating $\mathrm{CA}$ as a mediator, and knowledge base as a moderator in the relationship between IT competency and innovation in the SME context, this study offers new insights into the formation of such a relationship from the RBT perspective of IT.

In the next section, this study discusses a conceptual framework and reviews the relevant literature. It follows by hypotheses development that reflects the path relationship presented in the framework. Afterwards, this article describes the research method and then present and discusses findings. The conclusion section discusses the theoretical and 
managerial implications of the study, as well as the limitations and future research opportunities.

\section{BACKGROUND AND THEORETICAL FRAMEWORK}

\section{RBT Perspective of IT and Innovation}

The RBT perspective of IT provides an overarching theoretical lens to explain the relationship between IT competency and innovation. The theory's fundamental premise holds that IT competency facilitates value-creating activities which form the basis for its competitive advantage (Nevo and Wade, 2010; Pavlou and El Sawy, 2010). Innovation represents a form of value-creating activity that allows firms to achieve a competitive advantage in the marketplace ( $\mathrm{Li}$ and Atuahene-Gima, 2001; Zhou and $\mathrm{Li}, 2012$ ). A recent extension of the RBT perspective of IT posits that the possession of IT competency does not automatically allow firms to perform value-creating activities. Instead, the business value of IT competency arises due to leveraging the IT competency to facilitate other firm-level capabilities that enable firms to perform value-creating activities effectively (Kohli and Grover, 2008; Ravichandran and Lertwongsatien, 2005). Adopting this perspective, scholars have started to investigate how to position IT competency strategically to enhance various types of firm-level capabilities, which in turn facilitates innovation (e.g. Pavlou and El Sawy, 2006).

In terms of the empirical context, previous studies have attempted to explore the direct relationship between IT competency and innovation (e.g. Soto-Acosta et al., 2018), a few of which studies take a step further to investigate the shape of such a relationship in the SME context (e.g. Limaj et al., 2016). This study aims to enrich this indirect aspect of the IT competency-innovation relationship. More specifically, IT assimilation is a form of IT competency (Liu et al., 2016; Wade and Hulland, 2004) that reflect SMEs' focus on 
integrating IT into their business operations in order to improve their efficiency, effectiveness and flexibility (Levy and Powell, 2000). Exploratory and exploitative innovation represents two types of innovation activities that can create value and help SMEs to generate superior performance (Kollmann and Stöckmann, 2014). According to the RBT perspective of IT, IT assimilation influences these two types of innovation indirectly. This study aims to determine the specific firm-level capability and contingency that shapes this indirect relationship between IT assimilation and exploratory/exploitative innovation in the SME context.

\section{Contextual Ambidexterity}

The RBT perspective of IT suggests that the business value of IT competency derives from using it to support and enhance other firm-level capabilities (Kohli and Grover, 2008; Ravichandran and Lertwongsatien, 2005). Researchers have considered CA as a firm-level capability to pursue alignment and adaptability simultaneously (De Clercq et al., 2013; Raisch and Birkinshaw, 2008). In comparison to the structural approach, that focusses on creating separate business units (each of which focuses on one specific activity), CA focusses on firms' behavioral capacity to pursue distinct sets of activities simultaneously (Gibson and Birkinshaw, 2004). Since SMEs' resource constraints mean that the creation of multiple business units is problematic (De Clercq et al., 2014), therefore the adoption of CA offers a more feasible approach for achieving an ambidextrous posture in SMEs.

Furthermore, prior studies raise concern regarding the high-level resource demand for performing multiple tasks (i.e. alignment and adaptability) simultaneously during the implementation of an ambidextrous posture (e.g. Tushman and O'Reilly, 1996). According to the RBT perspective of IT, IT competency that permeates and infuses the ordinary business processes and activities enables firms to manage their resources more effectively (Nevo and Wade, 2010), which in turn allows the simultaneous implementation of multiple tasks 
(Dewett and Jones, 2001). This implies that resource-constricted SMEs with a high-level of IT competency are more likely to benefit from CA adoption.

Previous studies in different settings provide strong evidence to suggest that IT competency can enhance firms' ambidextrous posture (i.e. CA). For example, Im and Rai (2013) suggest that IT can be used to support firms' coordination mechanisms regarding their inter-organizational relationships. Using this form of IT competency can enable the simultaneous alignment of partners' activities and resources to meet short-term goals, and the adoption of partners' cognition and actions for long-term viability. On the other hand, prior studies also highlight that ambidextrous firms are more likely to create a favorable environment for enabling innovation (e.g. Kortmann, 2015). Based on the above discussion, this study concludes that CA may serve as a mediator in conveying the impacts of IT assimilation on exploratory/exploitative innovation in the SME context.

\section{Knowledge Base}

The RBT perspective of IT suggests that analyzing the effect of IT competency on firms' strategies requires a consideration of the contingency factors (Radhakrishnan et al., 2008; Wade and Hulland, 2004). Applying this insight, researchers have acknowledged the importance of the role of the knowledge that firms have obtained externally in facilitating the relationship between IT competency and innovation (e.g. Cui et al., 2015; Rai et al., 2012), but not the role of firms' internal knowledge. This study conceptualizes a knowledge base as a moderator in influencing the indirect relationship between IT competency and innovation by complementing the role of $\mathrm{CA}$ in such an indirect relationship.

This study investigates knowledge base for three reasons. Foremost, knowledge base represents firms' internal knowledge (De Luca and Atuahene-Gima, 2007; Zhou and Li, 2012) and determines the range of activities that firms are able to perform. Furthermore, knowledge 
base reflects the structure and content of firms' existing knowledge. There are two dimensions of a knowledge base. Knowledge breadth captures the structure of firms' knowledge horizontally and highlights the possession of heterogeneous knowledge content, whereas knowledge depth captures the structure of firms' knowledge vertically and highlights the possession of unique, complex, within-field knowledge content (Zhou and Li, 2012). Against this background, this study concludes that firms' knowledge base captures and delimits the scope of knowledge that they hold internally.

Lastly, the ways that firms process and transfer their knowledge can affect their ability to capitalize on their ambidextrous postures and perform value-creating activities to achieve superior performance (De Clercq et al., 2014; De Clercq et al., 2013). Different dimensions of knowledge base affect how knowledge is being processed and transferred within the firm (De Luca and Atuahene-Gima, 2007). Moreover, knowledge combination within different dimensions of the knowledge base can generate different innovative ideas (De Luca and Atuahene-Gima, 2007; Zahra and George, 2002). Taking the above reasons together, this study concludes that, when CA interacts with a different dimension of knowledge base, this may trigger different innovation activities, which in turn can affect the indirect relationship from IT assimilation through CA to exploratory/exploitative innovation.

\section{Hypotheses Development}

Drawing on the RBT perspective of IT (Radhakrishnan et al., 2008; Ravichandran and Lertwongsatien, 2005), this study anticipates a positive relationship between IT assimilation and CA. This is because, according to the logic of theory, IT assimilation reflects IT competency, which can then facilitate other firm-level capabilities, such as CA. More specifically, firms' ability to pursue alignment and adaptability goals simultaneously (CA) depends on their cross-functional coordination (Gibson and Birkinshaw, 2004). This is 
because, when pursuing two disparate goals simultaneously, organizations must provide the necessary management information (i.e. the status of resources - inventory, business tasks status, etc.) to support the members who reside in different functions (De Clercq et al., 2014; O'Reilly and Tushman, 2004). SMEs with high levels of IT assimilation are able to digitize their management information and so make it easily accessible to their members across the different functional units to ensure cross-functional coordination at a lower cost (Levy et al., 2003; Levy and Powell, 1998). Furthermore, simultaneously dealing with conflicting demands for alignment and adaptability goal-pursuing requires considerable resources (time, finance, etc.) (De Clercq et al., 2014; Gibson and Birkinshaw, 2004). With high levels of IT assimilation, SMEs are more capable of applying IT to support their various business functions and thus free up resources (Levy and Powell, 2000) to support CA engagement. To sum up, this study advocates that IT assimilation offers a favorable environment for resourceconstrained SMEs to enable CA.

Hypothesis 1: IT assimilation has a positive relationship with CA in SMEs.

The RBT perspective of IT also suggested that IT competency-enabled firm-level capabilities allow firms to perform value-creating activities effectively, which is the source of their competitive advantage (Kohli and Grover, 2008; Radhakrishnan et al., 2008). Based on this insight, this study proposes a relationship between CA (that represents a type of firmlevel capability) and exploratory/exploitative innovation (that reflects a firm's value-creating activities). More specifically, this study expects a positive relationship between CA and exploratory innovation ${ }^{5}$. Adaptive SMEs are able to reconfigure their business operations (e.g. re-allocating resources to different business functions to respond to changing business priorities) quickly to meet new demands (Akgün et al., 2012), which is an important antecedent for nurturing exploratory innovation (Kollmann and Stöckmann, 2014). Engaging in the pursuit of alignment goals, such as the development of effective internal collaboration 
(Acur et al., 2012), can help to speed up the process of reconfiguration, since high-level internal collaboration improves SMEs' ability to move resources across different business functions. Thus, when adaptive SMEs simultaneously pursue alignment goals, there are able to reconfigure the business operations quickly and provide a more favorable environment for exploratory innovation to take place.

This study also expects a positive relationship between CA and exploitation innovation. The pursuit of an alignment goal focuses on coordinating business activities across different functional units within SMEs to advance the operational efficiency (Acur et al., 2012; Prajogo and McDermott, 2014). This, in turn, fosters exploitation innovation, that places greater emphasis on incremental improvements (He and Wong, 2004). Adaptability goal-pursuit, such as encouraging employees to challenge outmoded traditions and practices (Akgün et al., 2012), helps firms to integrate more effectively by replacing the inefficient coordination (De Clercq et al., 2013; Raisch and Birkinshaw, 2008). When alignmentfocused SMEs simultaneously come to grips with the adaptability goal, they are able to enhance further the coherence among all of the patterns of activities within the firms and provide a foundation for exploitative innovation to occur.

Hypothesis 2: CA has a positive relationship with exploratory innovation in SMEs.

Hypothesis 3: CA has a positive relationship with exploitative innovation in SMEs

According to the RBT of IT, IT competency enables other firm-level capabilities, which in turn allows firms to perform value-creating activities in order to compete in the marketplace (Radhakrishnan et al., 2008; Ravichandran and Lertwongsatien, 2005). Following this logic, this study proposes a hypothesis regarding the indirect influence of IT assimilation (reflecting on IT competency) on innovation (reflecting on value-creating activity) through $\mathrm{CA}$ (reflecting on firm-level capabilities). As argued previously, IT assimilation allow SMEs to make their standard operational processes and routines more 
efficient (Liu et al., 2016). This not only frees up resources but also enhances crossfunctional collaboration. However, innovation does not appear simply because of the benefits arising from the integration of IT into the business operations. Instead, IT assimilation enables SMEs to develop a firm-level capability to pursue two disparate goals simultaneously (i.e. CA). Without IT assimilation, SMEs may find it difficult to establish CA successfully, because this can prove highly resource-demanding (Im and Rai, 2013). Ambidextrous SMEs are more able to reconfigure their business operations to explore new, improved approaches while at the same time ensuring effective collaboration among employees, who are working together to achieve the same goals (De Clercq et al., 2013). Therefore, CA may act as a precursor to exploratory innovation in the context of SME. On the other hand, ambidextrous SMEs are better able to maintain coherence among their activities while reconfiguring the business processes to meet the changing demands of the environment (De Clercq et al., 2014; Thongpapanl et al., 2012). Thus, CA is also an antecedent of exploitative innovation. Ambidextrous SMEs are able to make incremental improvements to the current product and service offers. In general, SMEs with a high-level of IT assimilation are better able to establish CA and realize its fruits - exploratory and exploitative innovation.

Hypothesis 4a: CA mediates the relationship between IT assimilation and exploratory innovation.

Hypothesis 4b: CA mediates the relationship between IT assimilation and exploitative innovation.

Drawing on the RBT perspective of IT and the CA literature, this study argues that knowledge base can affect the indirect IT assimilation-exploratory/exploitative innovation relationship by affecting the impact of $\mathrm{CA}$ on exploratory/exploitative innovation. The implementation of CA requires firms to shift their knowledge flexibility between the pursuit of alignment and adaptability (O'Reilly and Tushman, 2004). For ambidextrous SMEs to thrive, their internal knowledge exchange must be robust. Such exchanges provide an 
opportunity for combining knowledge and producing new ideas (De Clercq et al., 2014; De Clercq et al., 2013), which can influence the relationship between CA and innovation activities.

In particular, knowledge breadth enhances the influence of $\mathrm{CA}$ on exploratory innovation by increasing the supply of innovative ideas that are radical in nature. The combination of diverse know-how across a variety of disciplines and markets (knowledge breadth) in turn leads to the development of new, truly novel ideas (He and Wong, 2004; Zhou and Li, 2012). Ambidextrous SMEs are able to reconfigure their business operations quickly to position the firms strategically and so realize such ideas' commercial potential and simultaneously coordinate actions within the organizations to ensure the efficient execution of such tasks (De Clercq et al., 2013), which lays the foundation for exploratory innovation (Kortmann, 2015; Limaj et al., 2016). Thus, knowledge breadth is more likely to complement the use of CA in promoting exploratory innovation. In contrast, the combination of thorough experience and know-how about the existing technologies and markets (knowledge depth) is less likely to lead to ground-breaking innovative ideas (Kale and Singh, 2007). Without a healthy supply of ground-breaking innovative ideas, SMEs are unable to take advantage of their ambidextrous posture and translate these ideas into new products or services. Thus, CA is less likely to enhance exploratory innovation through its complementary relationship with knowledge depth in the SME context.

On the other hand, ambidextrous SMEs that focus on engaging in exploitative innovation are more likely to benefit from knowledge depth. The combination of thorough experience and know-how in specific industrial fields can help them to develop a deeper, more refined understanding of the existing technologies and markets (Kale and Singh, 2007; Zhou and Li, 2012). According to the literature, the innovative ideas derived from this kind of knowledge combination are more likely to support the incremental improvement of 
organizations' current practices (De Luca and Atuahene-Gima, 2007; Kollmann and Stöckmann, 2014). Ambidextrous SMEs can flexibly allocate firm resources across alignment and adaptability activities to ensure the effective implementation of these innovative ideas that focus on the incremental improvement of the current product and service offers. Thus, CA is more likely to enhance exploitative innovation in SMEs through its complementary relationship with knowledge depth. In contrast, SMEs with a knowledge base that contains distinct and multiple domains are less likely to develop innovative ideas that focus on incremental improvement through knowledge combination (Kale and Singh, 2007). Without a supply of innovative ideas related to refining and enhancing the existing offers, ambidextrous SMEs will be unable to capitalize on their ability simultaneously to reconfigure their business operations and maintain coherence among all patterns of their activities in order to convert these ideas into improved products or services. Therefore, knowledge breadth is less likely to complement the use of CA in promoting exploitative innovation.

Earlier, this study proposed that the indirect relationship started from IT assimilation through CA to exploratory/exploitative innovation. Assuming that knowledge breadth and knowledge depth will moderate the positive relationship between CA and exploratory/exploitative innovation differently, it is also likely that these dimensions of knowledge base will conditionally influence this indirect relationship. Hence, knowledge breadth and knowledge depth will act as contingency factors in the indirect IT assimilationexploratory/exploitative innovation relationship. This is in line with the RBT perspective of IT, that indicates that firms' ability to realize the full potential of IT competency depends on contingency factors (Radhakrishnan et al., 2008; Wade and Hulland, 2004). In this situation, knowledge breadth and knowledge depth act as contingency factors that affect the IT assimilation-exploratory/exploitative innovation relationship differently. As discussed, the possession of a broad knowledge base provides more opportunities for the members within 
ambidextrous firms to recombine different domains of knowledge and produce breakthrough ideas, which in turn promotes exploratory innovation. Thus, knowledge breadth is more likely to moderate the indirect IT assimilation-exploratory innovation relationship by influencing the effect of CA on exploratory innovation. Conversely, the possession of deep knowledge provides more opportunities for members within ambidextrous organizations to develop a more refined understanding of the existing technologies and markets and come up with ideas for incremental improvements, which in turn fosters exploitative innovation. Thus, knowledge depth is more likely to moderate the indirect IT assimilation-exploitative innovation relationship by influencing the effect of CA on exploitative innovation.

Hypothesis 5: Knowledge breadth improves the positive effects of CA on exploratory innovation, while knowledge depth suppresses the positive effects of CA on exploratory innovation, such that $\mathrm{CA}$ functions as a critical intermediate mechanism that connects IT assimilation and exploratory innovation when SMEs have a broad knowledge base (knowledge breadth) but not when they have a deep knowledge base (knowledge depth).

Hypothesis 6: Knowledge depth improves the positive effects of CA on exploitative innovation, while knowledge breadth suppresses the positive effects of CA on exploitative innovation, such that $\mathrm{CA}$ functions as a critical intermediate mechanism that connects IT assimilation and exploitative innovation when SMEs have a deep knowledge base (knowledge depth) but not when they have a broad knowledge base (knowledge breadth).

\section{RESEARCH METHOD}

\section{Measurement and Data Collection}

Upon investigation, there was no secondary data are available to test this study's framework (see Figure 1). Thus, this study collects new data through surveying executives from UK-based SMEs in the manufacturing sector (Hair et al., 2010). The researchers invited two executives from each organization to participate in order to capture the views from both the general management and the innovation sides. This study focuses on SMEs in the manufacturing sector for three reasons. First, the pursuit of innovation is a strategic movement that allows SME manufacturing firms to compete with large manufacturing firms 
in a mature marketplace ( $\mathrm{Li}$ and Atuahene-Gima, 2001). Second, scholars recognize the value of being an ambidextrous organization in the manufacturing sector (O'Reilly and Tushman, 2004) and SMEs are more likely to implement CA (De Clercq et al., 2014). Third, SME manufacturers use IT to support their business operations (Levy et al., 2003).

The items of the constructs originated in the extant literature (see Appendix 1). This study uses Likert scales ranging from 1 (strongly disagree) to 5 (strongly agree) to measure all of the items. Through using a cross-sectional research design, this study captures a snapshot of the value of all of the variables in the same time period. IT assimilation consists of the items used by Liu et al. (2016). Based on the items used by Gibson and Birkinshaw (2004), This study assesses alignment and adaptability, and calculate the product term of these two variables to form the CA measurement. This study adopts the measurement of knowledge breadth and knowledge depth from Zhou and Li (2012). For both exploratory innovation and exploitative innovation, the measurement items follow those of Kollmann and Stöckmann (2014).

Finally, this study includes six variables to account for the alternative explanations for the variations in firms' CA, exploratory innovation and exploitative innovation (e.g. Kollmann and Stöckmann, 2014; Kortmann, 2015). For firm size, the survey asked the CEOs to select one of the following options $(1=$ less than $50 ; 2=50-100 ; 3=101-150 ; 4=151$ $200 ; 5=200-250$ ) to indicate the number of full-time employees in the organization. For firm age, the survey asked the CEOs to choose one of the following options $(1=1-5$ years; $2=6$ 10 years; $3=11-15$ years; $4=16-20$ years; $5=$ more than 20 years) to indicate the number of years since the establishment of the organization. Dummies measured the firm's business activities (electronic goods, machinery and equipment parts, construction supply, automobile parts, consumer products, and others). From Liu et al. (2016), this study adopted a single item ("competition in our sector is fierce") to assess competitive intensity, a single item ("major 
changes occur frequently in the area of customer preferences in product/service features") to assess market dynamism, and a single item ("the rate of technology obsolescence is high in our industry") to assess technology turbulence.

The researchers conducted a pre-test by interviewing five representatives from different SMEs. They commented on all of the items on the survey. Based on their comments, the researchers refined and finalized the survey. For the full-scale research, the researchers obtained the UK company directory from the FAME database (FAME, 2016) and randomly selected 8000 SMEs with fewer than 250 employees. The data collection period was MarchSeptember 2017. The researchers first sent prospective respondents a pre-notification letter to request their participation. The researchers retained 1,358 companies that showed an interest in this study to form the survey sample pool. The researchers then sent a cover letter to the firm's CEO to ask him/her to answer the questions pertaining to the general management side, such as IT assimilation, alignment, adaptability, knowledge breadth, knowledge depth and control variables. For the innovation activities (exploratory/exploitative), the researchers asked the CEOs to pass the survey on to the individual responsible for managing this area (i.e. product manager) to complete. The researchers obtained dyadic responses from 248 SMEs, giving a response rate of $18.26 \%(248 / 1358)$. The researchers assessed the potential nonresponse bias by comparing the answers between the early and late respondents. The results show no significant differences between them.

"Insert Table 1 about Here"

\section{Validity and Reliability}

Although the collection of dyadic responses from both the general management side and the innovation side might reduce the common method bias, all of the questions were still answered by respondents from a single organization. Therefore, common method bias might 
threaten the validity of the results. The researchers followed the suggestions of Podsakoff et al. (2003) to use procedural remedies, such as offering anonymity to the respondents, to minimize the common method bias. Furthermore, the researchers also perform multiple statistical remedies (Podsakoff et al., 2003). First, the researchers perform Harman's singlefactor test by subjecting all of the items to exploratory factor analysis and find that this did not explain the majority of the variance. Second, the researchers used confirmatory factor analysis (CFA) to load all of the items onto a single factor in a CFA. The researchers found that the fit statistic does not show a good fit, which indicates that a single factor does not account for all of the variances. Both results suggest that common method variance is not a concern for this study.

To assess the construct validity, the researchers ran CFA. According to Hair et al. (2010), the overall model fits the data satisfactorily $\left(X^{2}=297.508 ; d f=168 ; X^{2} / d f=1.771 ; \mathrm{p}\right.$ $=.000$; comparative fit index $-\mathrm{CFI}=.945$; root mean square error of approximation RMSEA $=.056)$. The composite reliabilities $(\mathrm{CA})$ of each construct exceed the usual .70 benchmark. Thus, all of the constructs demonstrate adequate reliability and convergent validity. To test for discriminant validity, the researchers examine the variance related to each construct relative to its shared variance with the other constructs. The average variance extracted (AVE) of each construct exceeds the .50 benchmark. The researchers also find that the AVE of each construct is greater than all of its correlations with the other constructs. Thus, the degree of discriminant validity is adequate. The results are presented in Appendix 1.

\section{RESULTS}

\section{Hypothesis Testing}

The researchers performed multivariate regression analysis with an ordinary least squares estimator using IBM SPSS version 22. Table 2 presents the results. Model 1 and 2 
include only control variables that allow a direct comparison between the coefficients with respect to the relative explanatory power of the independent variables. Hypothesis 1 posits a positive association between IT assimilation and CA in the SME context. Table 3 shows that strong support exists for the prediction (Model 5: $\beta=.190, \mathrm{p}<.010$ ). The researchers also find strong support for Hypothesis 2 regarding the positive effect of CA on exploratory innovation (Model 6: $\beta=.478, \mathrm{p}<.001$ ), as well as Hypothesis 3 regarding the positive effect of CA on exploitative innovation (Model 7: $\beta=.282, \mathrm{p}<.001$ ).

"Insert Table 2 about here"

Hypothesis 4 infers that CA mediates the impacts of IT assimilation on a) exploratory innovation and b) exploitative innovation. These hypotheses are tested using the Hayes (2018)'s approach. First, the effect of IT assimilation (the independent variable) on CA (the mediating variable) is examined. As the earlier analysis shows for Model 5, the findings confirm this relationship. Second, the researchers examine the effects of CA (mediating variable) on exploratory innovation (Model 8: $\beta=.467, \mathrm{p}<.001$ ), as well as on exploitative innovation (Model 9: $\beta=.258, \mathrm{p}<.001$ ). In both situations, the researchers account for the effect of IT assimilation (independent variable). Finally, the indirect effect is calculated using a bootstrap analysis with 10,000 samples. The results suggest that the indirect effect between IT assimilation and exploratory innovation via CA is positive and significant (Models 5 and 8: $\beta=.089, \mathrm{p}<.050)$, with a 95\% confidence interval which does not include zero. This supports Hypothesis 4a. Similarly, the indirect effect between IT assimilation and exploitative innovation via CA is also positive and significant (Models 5 and 9: $\beta=.049, \mathrm{p}$ $<.050$ ), with a 95\% confidence interval which does not include zero. This supports Hypothesis $4 b$.

To investigate the differential moderated mediation effects in Hypotheses 5 and 6, the researchers follow the suggestions of Hayes (2018). The researchers begin by examining how 
knowledge breadth and knowledge depth influence the impacts of CA on exploratory innovation, as well as exploitative innovation. Model 12 shows that the interaction effect of CA and knowledge breadth on exploratory innovation is positive and significant (Model 12: $\beta$ $=.180, \mathrm{p}<.010)$, whereas the interaction of CA and knowledge depth does not affect exploratory innovation (Model 12: $\beta=-.035, \mathrm{p}>.050$ ). Model 15 shows that the interaction effect of CA and knowledge depth on exploitative innovation is positive and significant (Model 15: $\beta=.251, \mathrm{p}<.001$ ), whereas the interaction of CA and knowledge breadth has no effect on exploitative innovation (Model 15: $\beta=-.016, \mathrm{p}>.050$ ). The interaction plots are presented in Figure 2.

\section{"Insert Figure 2 about here"}

The researchers then test for the moderated mediating effect. Following Hayes (2018), the researchers estimate two full models (Models 16 and 17) which include all of the variables (and interaction terms). Using a bootstrap analysis with 10,000 samples, the researchers calculate the index of partial moderated mediation (IPMM). The results suggest that the IPMM of the indirect relationship from IT assimilation through CA to exploratory innovation is positive and significant, conditioned on knowledge breadth (Models 5 and 16: IPMM $=.034, \mathrm{p}<.050)$, with a 95\% confidence interval which does not include zero. However, the IPMM of the indirect relationship from IT assimilation through CA to exploratory innovation conditioned on knowledge depth is not significant (Models 5 and 16: IPMM $=-.007, \mathrm{p}>.050)$, with a $95 \%$ confidence interval including zero. This supports Hypothesis 5. The results suggest that the IPMM of the indirect relationship from IT assimilation through CA to exploitative innovation is positive and significant, conditioned on knowledge depth (Models 5 and 17: IPMM $=.047, \mathrm{p}<.050$ ), with a 95\% confidence interval which does not include zero. However, the IPMM of the indirect relationship from IT assimilation through CA to exploitative innovation, conditioned on knowledge breadth, is not 
significant (Models 5 and 17: IPMM $=-.003, \mathrm{p}>.050$ ), with a 95\% confidence interval including zero. This supports Hypothesis 6.

\section{Post-Hoc Probing}

The researchers conducted several robustness checks to verify the rigor of data analyses. Firstly, the researchers calculated and reported the variance inflation factors (VIFs) to assess the possibility of multicollinearity (see Table 2). The results show that all of the VIFs are below 3, which suggests that multicollinearity is not a problem in this analysis (Hair et al., 2010). Secondly, the researchers also calculated and reported the $95 \%$ confidence interval (Hair et al., 2010). The results match the hypotheses' tests (see Table 2). Thirdly, although the correlations (see Table 1) among the hypothesized variables ranged between .492 and .126, which Hinkle et al. (2003) consider a low or negligible level of correlation, however, they remain statistically significant. The researchers conducted an additional analysis regarding the possible cross-loading problem by employing principal component analysis with varimax rotation (see Appendix 2) ${ }^{6}$. The findings show that the loadings of each item for the associated construct are above .700 and that the loadings of other constructs are below .400 (Hair et al., 2010). Thus, the cross-loading problem is unlikely to be a challenge in regard to discriminant validity.

Fourthly, to verify the results of the interaction effects further, the researchers compared an R-square between the model with and without the interaction terms, following (Hayes, 2018). The significance of the R-square change and corresponding F-test is consistent with the earlier results (see Table 2). Fifthly, two interaction effects (CA x knowledge breadth; CA x knowledge depth) are estimated separately while controlling for each of the main effects (see Models 10-11, and 13-14). The results are consistent with the original approaches (see Models 12 and 15). Sixthly, the researchers undertook a path 
analysis (see Table 3) using AMOS 22.0. All of the results are consistent with the earlier findings from the multivariate regression analysis.

\section{"Insert Table 3 about here"}

Seventhly, the researchers determine whether the mediating effects are partial or full, following the suggestions of Baron and Kenny (1986). In step 1, the researchers confirm IT assimilation as a significant predictor of exploratory innovation (Model 3: $\beta=.142, p<.050$ ) and exploitative innovation (Model $4: \beta=.167, \mathrm{p}<.000$ ). The researchers already confirmed the relationship between IT assimilation and CA (Model 5: $\beta=.190, p<.050$ ) in the earlier analysis, which satisfies step 2, and also that CA is a significant predictor of both exploratory innovation (Model 8: $\beta=.467, p<.000$ ) and exploitative innovation (Model 9: $\beta=.258, p$ $<.000)$ when accounting for IT assimilation. Furthermore, as the direct effects of IT assimilation on exploratory innovation (Model 8: $\beta=.053, \mathrm{p}>.050$ ) and exploitative innovation (Model 9: $\beta=.118, \mathrm{p}>.050$ ) become insignificant, the indirect relationship is a full mediation relationship.

Finally, the researchers adopt two approaches to rule out potential endogeneity concerns. For the IT assimilation-CA relationship and moderating role of firms' knowledge base on the CA-exploratory/exploitive innovation relationship, the researchers adopt the hierarchical regression approach that Hamilton and Nickerson (2003) propose, which features widely in prior studies (e.g. Shou et al., 2016; Zhou and Li, 2012). In particular, IT assimilation is likely to be endogenous because firms' knowledge base (i.e. knowledge breadth and knowledge depth) provides the foundation for their ability to apply IT to support their business activities. To correct this endogeneity, the researchers regress IT assimilation

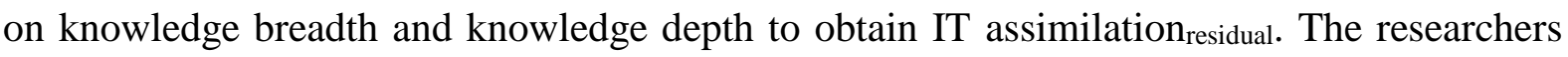
then replace IT assimilation with IT assimilation residual $_{\text {to }}$ examine the IT assimilation-CA relationship. Furthermore, firms' knowledge breadth and knowledge depth are also likely to 
be endogenous, because they are the result of having effective management practices (i.e. CA). To correct this endogeneity, the researchers use the same approach to regress the knowledge breadth and knowledge depth to CA, respectively, and derive the residuals of knowledge breadth and knowledge depth. The researchers then use knowledge breadth residual and knowledge depth $\mathrm{h}_{\text {residual }}$ as the indicators of knowledge breadth and knowledge depth to perform an interaction effects analysis. The results are consistent with the earlier findings (see Appendix 3).

For $\mathrm{CA}$ as a predictor of different innovation activities, the researchers adopt the approaches to compare the different groups of firms in the sample (Chang et al., 2016; Gibson and Birkinshaw, 2004). In particular, the researchers compare the level of exploratory innovation and exploitative innovation of "focused firms" (with either higher level ${ }^{7}$ alignment than adaptability or higher level adaptability than alignment) and "ambidextrous firms" (with an above average level of both dimensions). The focused firms have a mean exploratory innovation level of 3.856 and a mean exploitative innovation level of 3.785 , while ambidextrous firms have a mean exploratory innovation level of 4.090 and a mean exploitative innovation level of 4.022. The ANOVA $F$-test was significant when comparing the level of exploratory innovation $(F=8.389, \mathrm{p}<.010)$ and exploitative innovation $(F=$ 8.483, $\mathrm{p}<.010$ ) between focused firms and ambidextrous firms. The results confirm that firms' ability to be ambidextrous in an important predictor of their innovation activities.

\section{DISCUSSION AND CONCLUSION}

\section{Discussion of the Results}

This study aims to improve the current understanding of the relationship between IT competency and innovation by examining the intermediate mechanism that connects these two areas, as well as the contingent factor, that influence the entire indirect IT competencyinnovation relationship. This study adopts the RBT perspective of IT (Kohli and Grover, 
2008; Ravichandran and Lertwongsatien, 2005) as the theoretical foundation in this research. Drawing on the RBT perspective of IT, this study considers IT assimilation as IT competency and examine its indirect relationship with two types of innovation - exploratory innovation and exploitative innovation.

This study conceptualizes CA as a mediator in the IT competency-innovation relationship. By analyzing data collected from 248 UK-based SMEs in the manufacturing industry, the finding confirms that CA functions as a critical intermediate mechanism that connects IT assimilation and two types of innovation activities. This study reasons that CA helps SMEs to capitalize on their IT assimilation through simultaneously engaging in alignment and adaptability activities that center on the use of IT-enhanced cross-functional coordination. The engagement of CA enables SMEs to focus on improving their current operations and reconfiguration them to meet the changes in the environment (De Clercq et al., 2013; Thongpapanl et al., 2012), thus triggering different types of innovation. This implies that SMEs cannot fully realize the potential of their IT competency and use it to enable innovation without implementing CA.

This study also conceptualize two dimensions of knowledge base - knowledge breadth and knowledge depth - as moderators to influence the entire indirect relationship from IT assimilation through CA to exploratory/exploitative innovation by affecting the relationship between $\mathrm{CA}$ and two types of innovation activities. Knowledge breadth represents a wide range of diverse heterogeneous knowledge content, while knowledge depth represents complex within-field knowledge content (De Luca and Atuahene-Gima, 2007; Zhou and Li, 2012). The results of data analysis also confirm that knowledge breadth moderates the indirect IT assimilation-exploratory innovation relationship by influencing the effect of CA on exploratory innovation. Knowledge depth, on the other hand, moderates the indirect IT assimilation-exploitative innovation relationship by influencing the effect of CA 
on exploitative innovation. This study reasons that SMEs' ambidextrous posture serves two functions here: 1) demanding that SMEs transfer knowledge between alignment and adaptability activities and thus offer more opportunities for knowledge combination and 2) enabling SMEs effectively to convert innovative ideas into commercial benefits by simultaneously reconfiguring the business operations and maintaining coherence among all patterns of activities. The combination of broad knowledge across different fields often leads to ground-breaking innovative ideas, whereas the combination of in-depth knowledge in a specific field leads to innovative ideas that focus on making incremental improvements (Kale and Singh, 2007; Zahra and George, 2002). When encountering different types of innovative ideas, ambidextrous SMEs can effectively implement these ideas and thus promote different types of innovation. This result implies that SMEs can benefit from their IT assimilation that enables them to engage in $\mathrm{CA}$, which in turn allow them to perform innovation. However, it is apparent that the dimension of knowledge that SMEs hold internally can determine what types of innovation that they are able to perform.

\section{Theoretical Implications}

As a first contribution, this study adds to the IT competency-innovation literature by proposing CA as an intermediate mechanism to connect IT competency (IT assimilation) and innovation (exploratory/exploitative innovation). Building on the RBT perspective of IT, prior studies have recognized the direct linkage between IT competency and innovation (e.g. Soto-Acosta et al., 2018; Tarafdar and Gordon, 2007). In the recent development of the theory, scholars suggest that IT competency may influence innovation indirectly via enabling other firm-level capabilities (Kohli and Grover, 2008; Radhakrishnan et al., 2008). However, the theory fails to specify the type of firm-level capability that mediates the IT competencyinnovation relationship. This study addresses this gap by showing that CA reflects the firm- 
level capability (De Clercq et al., 2013; Raisch and Birkinshaw, 2008) that allows firms to capitalize on the benefits to their IT assimilation (a type of IT competency) and promote innovation (exploratory/exploitative innovation). In doing so, this study enriches the application of the RBT perspective of IT in the IT competency-innovation relationship studies by revealing the more precise underlying processes through which IT competency contributes to innovation. Furthermore, the previous literature has recognized the impacts of different types of IT competency on establishing an ambidextrous posture (e.g. Im and Rai, 2013), as well as the influence of an ambidextrous posture on innovation (e.g. Kortmann, 2015). However, these two research streams are divergent and disconnected, so this study represents an initial attempt to integrate them.

The second contribution is to introduce the knowledge base as a contingency factor in moderating the indirect IT competency-innovation relationship. In doing so, this study adds to the current understanding of the role of knowledge in the IT competency-innovation relationship. More specifically, the RBT perspective of IT suggests that firms' ability to realize the full potential of their IT competency depends on contingency factors (Radhakrishnan et al., 2008; Wade and Hulland, 2004). Drawing implicitly on this perspective, the prior research recognizes the role of external knowledge in affecting the IT competency-innovation relationship (e.g. Cui et al., 2015; Rai et al., 2012). The issue of how internal knowledge affects the IT competency-innovation relationship remains unexamined. In this research, this study shows that knowledge breadth complements $\mathrm{CA}$ in promoting exploratory innovation, whereas knowledge depth complements CA in promoting exploitative innovation. Different dimensions of knowledge base can affect the CAexploratory innovation relationship and CA-exploitative innovation relationship in different ways, affecting the indirect relationship from IT assimilation through CA to exploratory/exploitative innovation in distinctive ways. As a result, this study advances 
earlier streams of literature that focus on investigating the role of external knowledge in the IT competency-innovation relationship. This study enriches the application of the RBT perspective of IT in the IT competency-innovation relationship studies by not only demonstrating that firms' internal knowledge can influence the IT competency-innovation relationship but also differentiating the dimensions of internal knowledge to explicate their role in such relationships.

The final contribution pertains to the empirical context. Despite strong evidence that suggests that IT competency allows SMEs to utilize their limited resources more effectively and efficiently (Levy and Powell, 1998) while innovation represents a common route to value creation and is critical for SMEs attaining superior performance (Kollmann and Stöckmann, 2014), researchers have devoted less attention to understanding the IT competencyinnovation relationship in the SME context. This study enriches the IT competencyinnovation literature in the SME context (Limaj et al., 2016; Soto-Acosta et al., 2018) by examining a new theoretical framework for the first time. This study conceptualizes variables that reflect the SME context in the theoretical framework. More specifically, IT assimilation that describes firms' IT competency (Armstrong and Sambamurthy, 1999; Liu et al., 2016) reflects SMEs' ability to use IT as a business tool to create value and support their business practices rather than building complex IT infrastructures (Levy and Powell, 1998, 2000). CA is a more appropriate description for ambidextrous SMEs because it is unlikely that SMEs will develop separate structural units to handle their alignment and adaptability-oriented practices (De Clercq et al., 2014). Both types of innovation activities (Kollmann and Stöckmann, 2014; Limaj et al., 2016) and knowledge bases (Zhou and Li, 2012) are appropriate for the SME context. The finding of this study, in combination with those of previous studies, can provide valuable insights for both research and practice regarding how SMEs' IT competency can promote innovation. 


\section{Management Implications}

This study has several implications for SME managers. Firstly, SMEs managers generally integrate IT into firms' business operations as a way of promoting innovation (Soto-Acosta et al., 2018). The findings underscore the importance of paying more managerial attention to the underlying processes whereby IT competency stimulates innovation in the SME context (Limaj et al., 2016). More specifically, IT assimilation affects different types of innovation activities through CA. This means that SME managers who view innovation as their core competitive activities should focus their efforts not only on applying IT effectively in their business operations but also on enabling other firm-level capabilities (such as CA), which creates a more favorable internal environment for innovation to flourish. SME managers need to understand the comprehensive relationship among IT assimilation, CA, and innovation in order to monitor the process and focus their efforts on using IT to assist the simultaneous pursuit of alignment and adaptability goals, which in turn fosters exploratory/exploitative innovation.

Secondly, SME managers should not only concentrate on pursuing CA, but also invest in developing firms' knowledge base. For example, to improve the diversity and scope of firms' knowledge, SME managers might seek to promote activities such as rewarding information search activities beyond the existing customers or markets (Levy et al., 2003). To enhance the level of sophistication and complexity of the knowledge, SME managers might also focus their efforts on promoting activities such as refining the existing understanding of certain issues (Zhou and $\mathrm{Li}, 2012$ ). The results suggest that knowledge breadth moderates the indirect IT assimilation-exploratory innovation relationship by influencing the effect of CA on exploratory innovation, while knowledge depth moderates the indirect IT assimilationexploitative innovation relationship by influencing the effect of $\mathrm{CA}$ on exploitative 
innovation. Thus, SME managers must distinguish between knowledge breadth and knowledge depth, and understand their distinct roles in complementing the effects of CA. Resource-constrained SMEs may find it challenging to invest in developing both types of knowledge base at the same time. As a result, they sometimes need to be selective regarding their knowledge base development investment. If SME managers wish to focus on pursuing exploratory innovation, this study recommends that they invest in the development of knowledge breadth. If SME managers wish to focus on pursuing exploitative innovation, this study recommends that they invest in the development of knowledge depth.

\section{Limitations and Future Research Opportunities}

Firstly, in a cross-sectional study of this type, it is difficult to rule out problems related to endogeneity and draw any definite conclusions about the causation effect (i.e. the existence of reverse causality) among the variables over time, since a time lag may exist within the proposed causal relationship (Bucheli and Wadhwani, 2014; Mitchell and James, 2001). For example, the benefits of IT assimilation may take time to affect the implementation of CA. Furthermore, some of the variables that reflect specific organizational processes or resources may change periodically (Bucheli and Wadhwani, 2014; Lippmann and Aldrich, 2016). For example, SMEs may decide to change their IT strategies in different stages of the organization's life-cycle and so SMEs' knowledge base will accumulate over time. Future researchers might undertake a longitudinal study (Mitchell and James, 2001) or historical approach to assess the changes in the causal linkages throughout time, as well as changes in the variables in different time periods (Lippmann and Aldrich, 2016).

Secondly, the cross-sectional research design may also raise concerns about common method bias. However, the researchers believe that common method bias is unlikely to arise in this study's case because the researchers collect data from individuals with different 
functions in the company. Furthermore, multi-item scales and complex data relationships help to alleviate the possible concerns regarding common method bias, because the respondents were unable to guess the research hypotheses or respond in a socially desirable manner, that might lead to spurious findings (Podsakoff et al., 2003). Nevertheless, researchers in the future might employ a longitudinal research design in order to confirm this causality empirically or use objective data to combat this limitation.

Thirdly, although context-specific research provides practitioner insights for UKbased SMEs in the manufacturing industry, it is unclear whether this context (i.e. industry, company size, and country) impose a boundary constraint on the generalizability of this study's findings. Future research might extend this study to other research contexts to increase the generalizability of this study's findings. Fourthly, the researchers employ a single item to access the control variables related to environmental dynamism, such as competitive intensity, market turbulence and technology turbulence, based on the pilot study participants' feedback, who suggest that the questions related to these constructs are: 1) straightforward; and 2) easily captured using a single item. Nevertheless, the researchers recognize the potential bias that may arise due to using a single item measurement (Bergkvist and Rossiter, 2007) and suggest that future studies might adopt an objective measurement as a proxy for accessing the variables related to environmental dynamism.

Fifthly, in line with previous studies (Armstrong and Sambamurthy, 1999; Liu et al., 2016), this study fails to specify the different types of IT applications (i.e. enterprise resource planning, etc.) that a firm is capable of implementing when investigating the impact of IT assimilation. Due to the availability of a greater variety of IT applications with more complex functions, a firm may need to acquire a more specific competency in order to integrate these IT applications into its business operations effectively. Thus, future researchers should consider specifying the types of IT applications needed to obtain the true strategic 
ramifications of IT assimilation. Seventhly, although the researchers adopted the survey questions from prior studies and the further pilot study did not reveal any major issues regarding the wording of the questions, this study's survey-based research approach may limit the assessment of complex processes. For example, the phrase "we can" is used in the questions by Liu et al. (2016) to assess the firms" "capacity" to assimilate IT. However, these questions are unable to assess the degree to which the firms apply IT in supporting their business operations. Qualitative and interpretative approaches are necessary to gain deeper insights.

This study's findings also reveal other future research opportunities. The researchers examine the moderating role of knowledge base in the CA-innovation relationship, which raises the question of whether any other internal factors, such as resource competition (De Clercq et al., 2013), may either strengthen or weaken the CA-innovation relationship. Future researchers may wish to explore other IT competencies, such as managerial IT knowledge (Liu et al., 2016), as the potential antecedents of CA, which in turn fosters innovation. In general, the researchers hope that further research will continue to explore and document the IT competency-innovation relationship. 


\section{REFERENCE}

Acur, N., D. Kandemir, and H. Boer. 2012. Strategic alignment and new product development: Drivers and performance effects. Journal of Product Innovation Management, 29(2): 304-318.

Adler, P. S., B. Goldoftas, and D. I. Levine. 1999. Flexibility versus efficiency? A case study of model changeovers in the Toyota production system. Organization Science, 10(1): 43-68.

Akgün, A. E., H. Keskin, and J. Byrne. 2012. Antecedents and contingent effects of organizational adaptive capability on firm product innovativeness. Journal of Product Innovation Management, 29(1): 171-189.

Armstrong, C. P. and V. Sambamurthy. 1999. Information technology assimilation in firms: The influence of senior leadership and IT infrastructures. Information Systems Research, 10(4): 304-327.

Banker, R. D., I. Bardhan, and O. Asdemir. 2006. Understanding the impact of collaboration software on product design and development. Information Systems Research, 17(4): 352-373.

Baron, R. M. and D. A. Kenny. 1986. The moderator-mediator variable distinction in social psychological research: Conceptual, strategic, and statistical considerations. Journal of Personality and Social Psychology, 51(6): 1173-1182.

Bergkvist, L. and J. R. Rossiter. 2007. The predictive validity of multiple-item versus singleitem measures of the same constructs. Journal of Marketing Research, 44(2): 175-184.

Bucheli, M. and R. D. Wadhwani. 2014. Organizations in Time: History, theory, methods. Oxford: Oxford University Press.

Chang, Y.-C., P. Y. Yang, B. R. Martin, H.-R. Chi, and T.-F. Tsai-Lin. 2016. Entrepreneurial universities and research ambidexterity: A multilevel analysis. Technovation, 54(1): 7-21.

Cui, T., H. J. Ye, H. H. Teo, and J. Li. 2015. Information technology and open innovation: A strategic alignment perspective. Information \& Management, 52(3): 348-358.

De Clercq, D., N. Thongpapanl, and D. Dimov. 2014. Contextual ambidexterity in SMEs: The roles of internal and external rivalry. Small Business Economics, 42(1): 191-205.

De Clercq, D., N. T. Thongpapanl, and D. Dimov. 2013. Shedding new light on the relationship between contextual ambidexterity and firm performance: An investigation of internal contingencies. Technovation, 33(4): 119-132.

De Luca, L. M. and K. Atuahene-Gima. 2007. Market knowledge dimensions and crossfunctional collaboration: Examining the different routes to product innovation performance. Journal of Marketing, 71(1): 95-112.

Dewett, T. and G. R. Jones. 2001. The role of information technology in the organization: A review, model, and assessment. Journal of Management, 27(3): 313-346.

FAME. 2016. The definitive source of information on companies in the UK and Ireland. https://www.bvdinfo.com/en-gb/our-products/company-information/nationalproducts/fame; June, 2016

Gibson, C. B. and J. Birkinshaw. 2004. The antecedents, consequences, and mediating role of organizational ambidexterity. Academy of Management Journal, 47(2): 209-226.

Hair, J. F., W. Black, C., B. J. Babin, and R. E. Anderson. 2010. Multivariate data analysis (7th Edition). Upper Saddle River, NJ.: Prentice Hall.

Hamilton, B. H. and J. A. Nickerson. 2003. Correcting for endogeneity in strategic management research. Strategic Organization, 1(1): 51-78.

Hayes, A. F. 2018. Introduction to mediation, moderation, and conditional process analysis: A regression-based approach - $2^{\text {nd }}$ Edition New York: Guilford Press. 
He, Z. L. and P. K. Wong. 2004. Exploration vs. exploitation: An empirical test of the ambidexterity hypothesis. Organization Science, 15(4): 481-494.

Hinkle, D. E., W. Wiersma, and S. G. Jurs. 2003. Applied statistics for the behavioral sciences, 5th editions. Boston: Houghton Mifflin.

Im, G. and A. Rai. 2013. IT-enabled coordination for ambidextrous interorganizational relationships. Information Systems Research, 25(1): 72-92.

Kale, P. and H. Singh. 2007. Building firm capabilities through learning: The role of the alliance learning process in alliance capability and firm-level alliance success. Strategic Management Journal, 28(10): 981-1000.

Kohli, R. and V. Grover. 2008. Business value of IT: An essay on expanding research directions to keep up with the times. Journal of the Association for Information Systems, 9(1): 23-39.

Kollmann, T. and C. Stöckmann. 2014. Filling the entrepreneurial orientation-performance gap: The mediating effects of exploratory and exploitative innovations. Entrepreneurship Theory and Practice, 38(5): 1001-1026.

Kortmann, S. 2015. The mediating role of strategic orientations on the relationship between ambidexterity-oriented decisions and innovative ambidexterity. Journal of Product Innovation Management, 32(5): 666-684.

Levy, M., C. Loebbecke, and P. Powell. 2003. SMEs, co-opetition and knowledge sharing: the role of information systems. European Journal of Information Systems, 12(1): 317.

Levy, M. and P. Powell. 1998. SME flexibility and the role of information systems. Small Business Economics, 11(2): 183-196.

Levy, M. and P. Powell. 2000. Information systems strategy for small and medium sized enterprises: an organisational perspective. Journal of Strategic Information Systems, 9(1): 63-84.

Li, H. and K. Atuahene-Gima. 2001. Product innovation strategy and the performance of new technology ventures in China. Academy of Management Journal, 44(6): 1123-1134.

Limaj, E., E. W. Bernroider, and J. Choudrie. 2016. The impact of social information system governance, utilization, and capabilities on absorptive capacity and innovation: A case of Austrian SMEs. Information \& Management, 53(3): 380-397.

Lippmann, S. and H. E. Aldrich. 2016. The temporal dimension of context. In Welter, F. \& W. B. Gartner (Eds.), A Research Agenda for Entrepreneurship and Context. Cheltenham: Edward Elgar.

Liu, H., S. Wei, W. Ke, K. K. Wei, and Z. Hua. 2016. The configuration between supply chain integration and information technology competency: A resource orchestration perspective. Journal of Operations Management, 44(3): 13-29.

Mitchell, T. R. and L. R. James. 2001. Building better theory: Time and the specification of when things happen. Academy of Management Review, 26(4): 530-547.

Nevo, S. and M. R. Wade. 2010. The formation and value of IT-enabled resources: Antecedents and consequences of synergistic relationships. MIS Quarterly, 34(1): 163-183.

O'Mahony, R., L. Padmore, and B. Suh. 2003. The innovator's advantage: Using innovation and technology to improve business performance. London: Accenture.

O'Reilly, C. A. and M. L. Tushman. 2004. The ambidextrous organization. Harvard Business Review, 82(4): 74-81, 140.

Patel, P. C., J. G. Messersmith, and D. P. Lepak. 2013. Walking the tightrope: An assessment of the relationship between high-performance work systems and organizational ambidexterity. Academy of Management Journal, 56(5): 1420-1442. 
Pavlou, P. A. and O. A. El Sawy. 2006. From IT leveraging competence to competitive advantage in turbulent environments: The case of new product development. Information Systems Research, 17(3): 198-227.

Pavlou, P. A. and O. A. El Sawy. 2010. The "third hand": IT-enabled competitive advantage in turbulence through improvisational capabilities. Information Systems Research, 21(3): 443-471.

Podsakoff, P. M., S. B. MacKenzie, J. Y. Lee, and N. P. Podsakoff. 2003. Common method biases in behavioral research: a critical review of the literature and recommended remedies. Journal of Applied Psychology, 88(5): 879-903.

Prajogo, D. and C. M. McDermott. 2014. Antecedents of service innovation in SMEs: Comparing the effects of external and internal factors. Journal of Small Business Management, 52(3): 521-540.

Radhakrishnan, A., X. Zu, and V. Grover. 2008. A process-oriented perspective on differential business value creation by information technology: An empirical investigation. Omega, 36(6): 1105-1125.

Rai, A., P. A. Pavlou, G. Im, and S. Du. 2012. Interfirm IT capability profiles and communications for cocreating relational value: evidence from the logistics industry. MIS Quarterly, 36(1): 233-262.

Raisch, S. and J. Birkinshaw. 2008. Organizational ambidexterity: Antecedents, outcomes, and moderators. Journal of Management, 34(3): 375-409.

Ravichandran, T. and C. Lertwongsatien. 2005. Effect of information systems resources and capabilities on firm performance: A resource-based perspective. Journal of Management Information Systems, 21(4): 237-276.

Shou, Z., X. V. Zheng, and W. Zhu. 2016. Contract ineffectiveness in emerging markets: An institutional theory perspective. Journal of Operations Management, 46(1): 38-54.

Soto-Acosta, P., S. Popa, and I. Martinez-Conesa. 2018. Information technology, knowledge management and environmental dynamism as drivers of innovation ambidexterity: A study in SMEs. Journal of Knowledge Management: https://doi.org/10.1108/JKM1110-2017-0448.

Tarafdar, M. and S. R. Gordon. 2007. Understanding the influence of information systems competencies on process innovation: A resource-based view. Journal of Strategic Information Systems, 16(4): 353-392.

Thongpapanl, N. T., D. De Clercq, and D. Dimov. 2012. An investigation of the performance consequences of alignment and adaptability: Contingency effects of decision autonomy and shared responsibility. $R \& D$ Management, 42(1): 14-30.

Tushman, M. L. and C. A. O'Reilly. 1996. Ambidextrous organizations: Managing evolutionary and revolutionary change. California Management Review, 38(4): 8-29.

Wade, M. and J. Hulland. 2004. The resource-based view and information systems research: Review, extension, and suggestions for future research. MIS Quarterly, 28(1): 107142.

Zahra, S. A. and G. George. 2002. Absorptive capacity: A review, reconceptualization, and extension. Academy of Management Review, 27(2): 185-203.

Zhou, K. Z. and C. B. Li. 2012. How knowledge affects radical innovation: Knowledge base, market knowledge acquisition, and internal knowledge sharing. Strategic Management Journal, 33(9): 1090-1102. 
Figure 1: Conceptual Framework

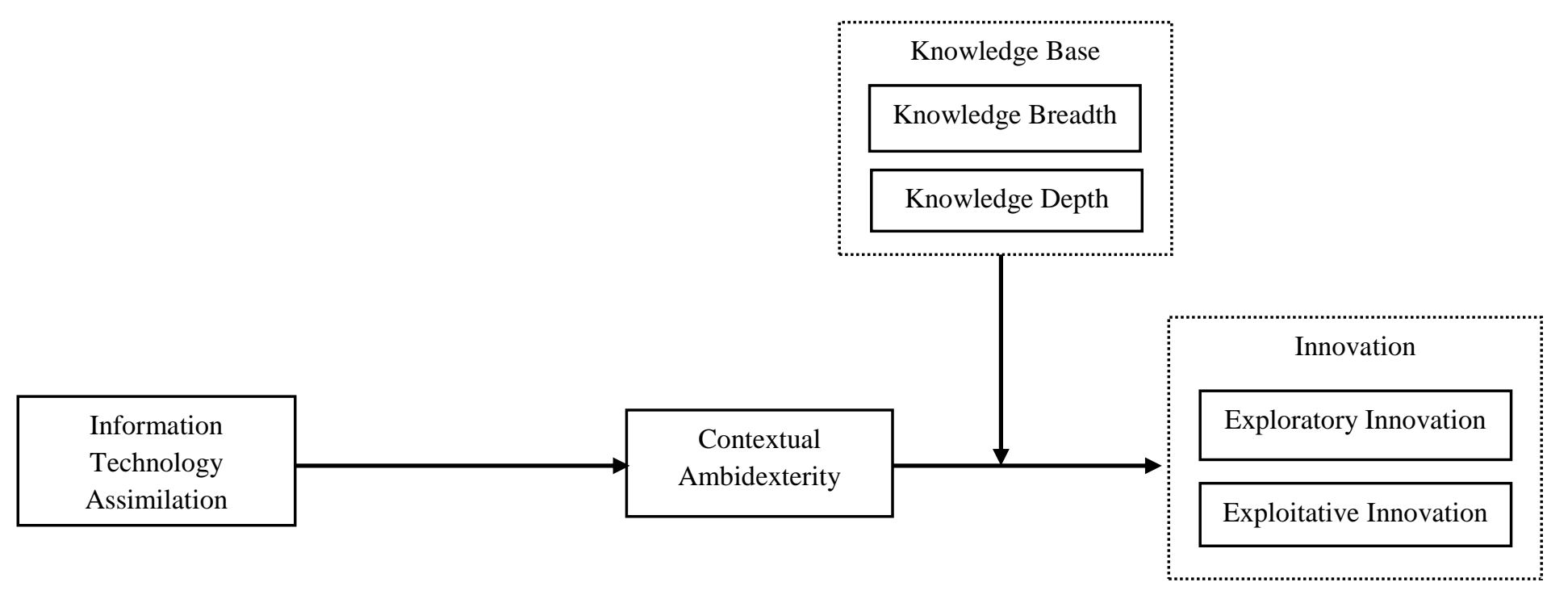

Control Variable - Business Activities

- Firm Size

- Firm Age

- Competitive Intensity

- Market Turbulence

- Technology Turbulence 
Table 1: Descriptive Statistics

\begin{tabular}{|c|c|c|c|c|c|c|c|c|c|c|c|c|c|c|c|c|c|c|c|}
\hline & Mean & SD & 1 & 2 & 3 & 4 & 5 & 6 & 7 & 8 & 9 & 10 & 11 & 12 & 13 & 14 & 15 & 16 & 17 \\
\hline 1. Electronic Goods & --- & --- & --- & & & & & & & & & & & & & & & & \\
\hline 2. Machinery and Equipment Parts & --- & --- & $-.186^{*}$ & --- & & & & & & & & & & & & & & & \\
\hline 3. Construction Products & --- & --- & $-.183 *$ & $-.145^{*}$ & --- & & & & & & & & & & & & & & \\
\hline 4. Automobile Parts & --- & -- & $-.173 *$ & $-.137 *$ & $-.135 *$ & --- & & & & & & & & & & & & & \\
\hline 5. Consumer Products & --- & --- & $-.264 *$ & $-.210 *$ & $-.206^{*}$ & $-.195 *$ & --- & & & & & & & & & & & & \\
\hline 6. Firm Size & 3.500 & 1.532 & .104 & $-.173^{*}$ & $-.171 *$ & $-.158 *$ & $.254^{*}$ & --- & & & & & & & & & & & \\
\hline 7. Firm Age & 2.640 & 1.469 & -.113 & $.201 *$ & .093 & -.060 & -.089 & -.112 & -- & & & & & & & & & & \\
\hline 8. Competitive Intensity & 3.750 & 1.087 & .119 & -.057 & -.038 & -.084 & .036 & .052 & -.025 & --- & & & & & & & & & \\
\hline 9. Market Turbulence & 3.630 & 1.231 & .097 & .049 & -.043 & -.067 & -.036 & .020 & .095 & $.251 *$ & --- & & & & & & & & \\
\hline 10. Technology Turbulence & 3.730 & 1.182 & -.062 & .018 & .067 & .007 & .046 & .009 & .034 & .102 & $.344 *$ & --- & & & & & & & \\
\hline $\begin{array}{l}\text { 11. Information Technology } \\
\text { Assimilation }\end{array}$ & 3.751 & 1.215 & .048 & -.113 & .007 & .073 & .038 & .038 & -.055 & -.063 & -.069 & $-.130^{*}$ & .888 & & & & & & \\
\hline 12. Alignment & 4.227 & .732 & .028 & -.010 & .027 & -.076 & -.021 & .055 & -.049 & -.084 & $-.193 *$ & $-.137 *$ & $.135^{*}$ & .770 & & & & & \\
\hline 13. Adaptability & 4.258 & .725 & .036 & -.110 & -.022 & .014 & -.009 & .044 & -.025 & $-.142 *$ & $-.204 *$ & $-.156^{*}$ & $.221^{*}$ & $.492 *$ & .763 & & & & \\
\hline 14. Knowledge Breadth & 3.839 & 1.078 & .041 & -.030 & .047 & .058 & -.067 & .043 & -.010 & .094 & -.035 & .071 & $.168^{*}$ & $.137^{*}$ & $.126^{*}$ & .795 & & & \\
\hline 15. Knowledge Depth & 3.742 & 1.065 & .075 & $-.133 *$ & .027 & $-.129 *$ & .124 & $.167^{*}$ & $-.148 *$ & .074 & .020 & .008 & $.133^{*}$ & $.276^{*}$ & $.225 * *$ & $.268^{*}$ & .719 & & \\
\hline 16. Exploratory Innovation & 3.917 & .872 & .109 & -.046 & -.006 & -.039 & -.010 & -.015 & -.065 & .007 & -.036 & .035 & $.138^{*}$ & $.402^{*}$ & $.387 * *$ & $.345^{*}$ & $.286^{*}$ & .794 & \\
\hline 17. Exploitative Innovation & 3.823 & 1.022 & .037 & -.059 & -.054 & .004 & .086 & -.028 & -.038 & .112 & $-.165^{*}$ & -.007 & $.165^{*}$ & $.203^{*}$ & $.272 * *$ & $.266^{*}$ & $.368^{*}$ & $.336^{*}$ & .759 \\
\hline
\end{tabular}

17. Exploitative Innovation

$\begin{array}{llllll}3.823 & 1.022 & 037 & -.059 & -.054 & .0\end{array}$

$\mathrm{N}=248 ; \mathrm{*}<<.05$

(AVE) square roots are shown in bold on the correlation matrix diagonal

Business Activities Dummies: the researchers choose "Others" as the benchmark group 
Table 2: Findings

\begin{tabular}{|c|c|c|c|c|c|c|c|c|c|c|c|c|c|c|c|c|c|c|}
\hline \multirow[b]{4}{*}{ Electronic Goods } & \multirow{2}{*}{\multicolumn{2}{|c|}{$\begin{array}{c}\text { Model 1 } \\
\text { Exploratory } \\
\text { Innovation }\end{array}$}} & \multirow{2}{*}{\multicolumn{2}{|c|}{$\begin{array}{c}\text { Model 2 } \\
\text { Exploitative } \\
\text { Innovation }\end{array}$}} & \multirow{2}{*}{\multicolumn{2}{|c|}{$\begin{array}{c}\text { Model 3 } \\
\text { Exploratory } \\
\text { Innovation }\end{array}$}} & \multirow{2}{*}{\multicolumn{2}{|c|}{$\begin{array}{c}\text { Model 4 } \\
\text { Exploitative } \\
\text { Innovation }\end{array}$}} & \multirow{2}{*}{\multicolumn{2}{|c|}{$\begin{array}{c}\text { Model } 5 \\
\text { Contextual } \\
\text { Ambidexterity }\end{array}$}} & \multirow{2}{*}{\multicolumn{2}{|c|}{$\begin{array}{c}\text { Model } 6 \\
\text { Exploratory } \\
\text { Innovation }\end{array}$}} & \multirow{2}{*}{\multicolumn{2}{|c|}{$\begin{array}{c}\text { Model } 7 \\
\text { Exploitative } \\
\text { Innovation }\end{array}$}} & \multirow{2}{*}{\multicolumn{2}{|c|}{$\begin{array}{c}\text { Model 8 } \\
\text { Exploratory } \\
\text { Innovation }\end{array}$}} & \multirow{2}{*}{\multicolumn{2}{|c|}{$\begin{array}{c}\text { Model 9 } \\
\text { Exploitative } \\
\text { Innovation }\end{array}$}} \\
\hline & & & & & & & & & & & & & & & & & & \\
\hline & & VIF & & VIF & & VIF & & VIF & & VIF & & VIF & & VIF & & VIF & & VIF \\
\hline & $\begin{array}{l}.108(1.351) \\
{[-.110, .591]}\end{array}$ & 1.56 & $\begin{array}{c}.064(.818) \\
{[-.234, .567]}\end{array}$ & 1.56 & $\begin{array}{l}.097(1.211) \\
{[-.134, .563]}\end{array}$ & 1.57 & $\begin{array}{c}.050(.648) \\
{[-.266, .527]}\end{array}$ & 1.57 & $\begin{array}{c}.005(.070) \\
{[-1.881,2.020]}\end{array}$ & 1.57 & $\begin{array}{l}.098(1.377) \\
{[-.094, .530]}\end{array}$ & 1.56 & $\begin{array}{c}.058(.771) \\
{[-.235, .537]}\end{array}$ & 1.56 & $\begin{array}{l}.094(1.315) \\
{[-.104, .522]}\end{array}$ & 1.57 & $\begin{array}{c}.049(.650) \\
{[-.258, .511]}\end{array}$ & 1.57 \\
\hline Machinery and Equipment Parts & $\begin{array}{l}-.026(-.337) \\
{[-.466, .330]}\end{array}$ & 1.47 & $\begin{array}{l}-.028(-.368) \\
{[-.539, .369]}\end{array}$ & 1.47 & $\begin{array}{c}-.019(-.249) \\
{[-.445, .345]}\end{array}$ & 1.47 & $\begin{array}{l}-.020(-.263) \\
{[-.509, .389]}\end{array}$ & 1.47 & $\begin{array}{c}-.072(-.972) \\
{[-3.297,1.119]}\end{array}$ & 1.47 & $\begin{array}{c}.012(.180) \\
{[-.322, .387]}\end{array}$ & 1.47 & $\begin{array}{l}-.005(-.070) \\
{[-.454, .423]}\end{array}$ & 1.47 & $\begin{array}{c}.014(.205) \\
{[-.318, .392]}\end{array}$ & 1.48 & $\begin{array}{l}-.001(-.017) \\
{[-.440, .433]}\end{array}$ & 1.48 \\
\hline Construction Products & $\begin{array}{l}-.004(-.053) \\
{[-.411, .389]}\end{array}$ & 1.44 & $\begin{array}{l}-.047(-.623) \\
{[-.602, .312]}\end{array}$ & 1.44 & $\begin{array}{l}-.012(-.161) \\
{[-.430, .365]}\end{array}$ & 1.45 & $\begin{array}{l}-.057(-.762) \\
{[-.627, .277]}\end{array}$ & 1.45 & $\begin{array}{c}-.037(-.512) \\
{[-2.800,1.644]}\end{array}$ & 1.45 & $\begin{array}{c}.009(.124) \\
{[-.334, .378]}\end{array}$ & 1.45 & $\begin{array}{l}-.039(-.545) \\
{[-.562, .318]}\end{array}$ & 1.45 & $\begin{array}{c}.005(.075) \\
{[-.343, .370]}\end{array}$ & 1.45 & $\begin{array}{l}-.047(-.652) \\
{[-.583, .293]}\end{array}$ & 1.45 \\
\hline Automobile Parts & $\begin{array}{l}-.038(-.502) \\
{[-.517, .307]}\end{array}$ & 1.40 & $\begin{array}{c}.008(.111) \\
{[-.444, .497]}\end{array}$ & 1.40 & $\begin{array}{l}-.053(-.697) \\
{[-.556, .265]}\end{array}$ & 1.41 & $\begin{array}{l}-.009(-.123) \\
{[-.496, .438]}\end{array}$ & 1.41 & $\begin{array}{c}-.085(-1.172) \\
{[-3.660, .930]}\end{array}$ & 1.41 & $\begin{array}{c}-.007(-.105) \\
{[-.387, .348]}\end{array}$ & 1.41 & $\begin{array}{c}.027(.371) \\
{[-.368, .540]}\end{array}$ & 1.41 & $\begin{array}{l}-.013(-.194) \\
{[-.406, .333]}\end{array}$ & 1.42 & $\begin{array}{c}.013(.179) \\
{[-.413, .495]}\end{array}$ & 1.42 \\
\hline Consumer Products & $\begin{array}{c}.006(.075) \\
{[-.323, .348]}\end{array}$ & 1.64 & $\begin{array}{l}.091(1.133) \\
{[-.163, .604]}\end{array}$ & 1.64 & $\begin{array}{c}-.005(-.064) \\
{[-.344, .323]}\end{array}$ & 1.65 & $\begin{array}{c}.078(.976) \\
{[-.191, .567]}\end{array}$ & 1.65 & $\begin{array}{c}-.076(-.975) \\
{[-2.787, .942]}\end{array}$ & 1.65 & $\begin{array}{c}.035(.481) \\
{[-.226, .372]}\end{array}$ & 1.65 & $\begin{array}{l}.108(1.397) \\
{[-.107, .631]}\end{array}$ & 1.65 & $\begin{array}{c}.030(.413) \\
{[-.237, .363]}\end{array}$ & 1.66 & $\begin{array}{l}.097(1.259) \\
{[-.133, .604]}\end{array}$ & 1.66 \\
\hline Firm Size & $\begin{array}{c}-.044(-.638) \\
{[-.103, .052]}\end{array}$ & 1.16 & $\begin{array}{l}-.073(-1.076) \\
{[-.137, .040]}\end{array}$ & 1.16 & $\begin{array}{l}-.048(-.702) \\
{[-.104, .050]}\end{array}$ & 1.16 & $\begin{array}{c}-.077(-1.161) \\
{[-.139, .036]}\end{array}$ & 1.16 & $\begin{array}{c}.043(.654) \\
{[-.287, .573]}\end{array}$ & 1.16 & $\begin{array}{l}-.067(-1.091) \\
{[-.107, .031]}\end{array}$ & 1.16 & $\begin{array}{l}-.086(-1.326) \\
{[-.143, .028]}\end{array}$ & 1.16 & $\begin{array}{l}-.068(-1.106) \\
{[-.108, .030]}\end{array}$ & 1.16 & $\begin{array}{l}-.088(-1.368) \\
{[-.144, .026]}\end{array}$ & 1.16 \\
\hline Firm Age & $\begin{array}{l}-.049(-.741) \\
{[-.107, .049]}\end{array}$ & 1.08 & $\begin{array}{c}.003(.044) \\
{[-.087, .091]}\end{array}$ & 1.08 & $\begin{array}{l}-.046(-.702) \\
{[-.105, .050]}\end{array}$ & 1.08 & $\begin{array}{c}.006(.099) \\
{[-.084, .093]}\end{array}$ & 1.08 & $\begin{array}{c}.003(.046) \\
{[-.423, .443]}\end{array}$ & 1.08 & $\begin{array}{l}-.049(-.824) \\
{[-.099, .040]}\end{array}$ & 1.08 & $\begin{array}{c}.003(.051) \\
{[-.084, .088]}\end{array}$ & 1.08 & $\begin{array}{l}-.048(-.805) \\
{[-.098, .041]}\end{array}$ & 1.08 & $\begin{array}{c}.006(.090) \\
{[-.082, .089]}\end{array}$ & 1.08 \\
\hline Competitive Intensity & $\begin{array}{l}-.001(-.011) \\
{[-.106, .105]}\end{array}$ & 1.09 & $\begin{array}{l}.153(2.347)^{*} \\
{[.023, .265]}\end{array}$ & 1.09 & $\begin{array}{c}.007(.108) \\
{[-.099, .111]}\end{array}$ & 1.09 & $\begin{array}{l}.163(2.517) \\
{[.033, .273]}\end{array}$ & 1.09 & $\begin{array}{l}-.088(-1.378) \\
{[-1.000, .177]}\end{array}$ & 1.09 & $\begin{array}{c}.046(.771) \\
{[-.058, .132]}\end{array}$ & 1.10 & $\begin{array}{c}.181(2.865)^{* *} \\
{[.053, .287]}\end{array}$ & 1.10 & $\begin{array}{c}.048(.802) \\
{[-.056, .133]}\end{array}$ & 1.10 & $\begin{array}{c}.185(2.946) * * \\
{[.058, .291]}\end{array}$ & 1.10 \\
\hline Market Turbulence & $\begin{array}{c}-.065(-.905) \\
{[-.145, .054]}\end{array}$ & 1.24 & $\begin{array}{c}-.225(-3.238) * * \\
{[-.301,-.073]}\end{array}$ & 1.24 & $\begin{array}{c}-.064(-.905) \\
{[-.144, .053]}\end{array}$ & 1.24 & $\begin{array}{c}-.225(-3.269) * * \\
{[-.299,-.074]}\end{array}$ & 1.24 & $\begin{array}{c}-.192(-2.843)^{* *} \\
{[-1.350,-.245]}\end{array}$ & 1.24 & $\begin{array}{c}.028(.427) \\
{[-.071, .110]}\end{array}$ & 1.28 & $\begin{array}{c}-.171(-2.512)^{*} \\
{[-.253,-.031]}\end{array}$ & 1.28 & $\begin{array}{c}.026(.398) \\
{[-.072, .108]}\end{array}$ & 1.28 & $\begin{array}{c}-.175(-2.585)^{*} \\
{[-.256,-.035]}\end{array}$ & 1.28 \\
\hline Technology Turbulence & $\begin{array}{c}.067(.970) \\
{[-.051, .150]}\end{array}$ & 1.16 & $\begin{array}{c}.059(.873) \\
{[-.064, .166]}\end{array}$ & 1.16 & $\begin{array}{l}.085(1.228) \\
{[-.038, .163]}\end{array}$ & 1.18 & $\begin{array}{l}.080(1.189) \\
{[-.045, .183]}\end{array}$ & 1.18 & $\begin{array}{c}-.077(-1.163) \\
{[-.893, .230]}\end{array}$ & 1.18 & $\begin{array}{c}.115(1.862) \\
{[-.005, .175]}\end{array}$ & 1.17 & $\begin{array}{l}.087(1.336) \\
{[-.036, .186]}\end{array}$ & 1.17 & $\begin{array}{l}.121(1.941) \\
{[-.001, .179]}\end{array}$ & 1.18 & $\begin{array}{c}.100(1.527) \\
{[-.025, .197]}\end{array}$ & 1.18 \\
\hline $\begin{array}{l}\text { Information Technology } \\
\text { Assimilation }\end{array}$ & & & & & .142 & 1.05 & 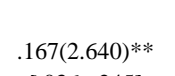 & 1.05 & & 1.05 & & & & & .053 & 1.09 & .118 & 1.09 \\
\hline Contextual Ambidexterity & & & & & & & & & & & $\begin{array}{c}.478(7.966) * * * * \\
{[.061, .102]}\end{array}$ & 1.10 & $\begin{array}{c}.282(4.451)^{* * * *} \\
{[.031, .081]}\end{array}$ & 1.10 & $\begin{array}{c}{[-.046, .122]} \\
.467(7.637)^{* * *} \\
{[.059, .100]}\end{array}$ & 1.15 & $\begin{array}{c}{[-.004, .203]} \\
.258(4.021)^{* * * *} \\
{[.026, .077]}\end{array}$ & 1.15 \\
\hline
\end{tabular}

Knowledge Depth (KD)

Contextual Ambidexterity x KB

Contextual Ambidexterity x KD

\begin{tabular}{|c|c|c|c|c|c|c|c|c|c|}
\hline F-Value & .559 & 1.791 & 1.841 & 2.303 & 3.127 & 6.411 & 3.559 & 5.937 & 3.594 \\
\hline P-Value & .847 & .063 & .043 & .011 & .000 & .000 & .000 & .000 & .000 \\
\hline R-Square & .023 & .070 & .086 & .097 & .127 & .230 & .142 & .233 & .155 \\
\hline Adjusted R-Square & -.018 & .031 & .043 & .055 & .086 & .194 & .102 & .194 & .112 \\
\hline
\end{tabular}

Note: $* * * \mathrm{p}<0.001 ; * * \mathrm{p}<0.010 ; * \mathrm{p}<0.050 ; \mathrm{VIF}=$ Variance Inflation Factors

Standardized Coefficients are reported with (t-value) in parentheses and 95\% confidence interval in the brackets [lower bound, upper bound] 
Table 2: Findings (Continued)

\begin{tabular}{|c|c|c|c|c|c|c|c|c|c|c|c|c|c|c|c|c|}
\hline & \multirow{2}{*}{\multicolumn{2}{|c|}{$\begin{array}{c}\text { Model 10 } \\
\text { Exploratory } \\
\text { Innovation }\end{array}$}} & \multirow{2}{*}{\multicolumn{2}{|c|}{$\begin{array}{c}\text { Model 11 } \\
\text { Exploratory } \\
\text { Innovation } \\
\end{array}$}} & \multirow{2}{*}{\multicolumn{2}{|c|}{$\begin{array}{c}\text { Model 12 } \\
\text { Exploratory } \\
\text { Innovation } \\
\end{array}$}} & \multirow{2}{*}{\multicolumn{2}{|c|}{$\begin{array}{c}\text { Model 13 } \\
\text { Exploitative } \\
\text { Innovation } \\
\end{array}$}} & \multirow{2}{*}{\multicolumn{2}{|c|}{$\begin{array}{c}\text { Model 14 } \\
\text { Exploitative } \\
\text { Innovation }\end{array}$}} & \multirow{2}{*}{\multicolumn{2}{|c|}{$\begin{array}{l}\text { Model 15 } \\
\text { Exploitative } \\
\text { Innovation }\end{array}$}} & \multirow{2}{*}{\multicolumn{2}{|c|}{$\begin{array}{l}\text { Model 16 } \\
\text { Exploratory } \\
\text { Innovation }\end{array}$}} & \multirow{2}{*}{\multicolumn{2}{|c|}{$\begin{array}{c}\text { Model 17 } \\
\text { Exploitative } \\
\text { Innovation } \\
\end{array}$}} \\
\hline & & & & & & & & & & & & & & & & \\
\hline & & VIF & & VIF & & VIF & & VIF & & VIF & & VIF & & VIF & & VIF \\
\hline Electronic Goods & $\begin{array}{l}.093(1.394) \\
{[-.085, .498]}\end{array}$ & 1.57 & $\begin{array}{l}.084(1.232) \\
{[-.112, .484]}\end{array}$ & 1.57 & $\begin{array}{l}.095(1.416) \\
{[-.082, .502]}\end{array}$ & 1.57 & $\begin{array}{c}.038(.544) \\
{[-.262, .463]}\end{array}$ & 1.57 & $\begin{array}{c}.027(.401) \\
{[-.278, .420]}\end{array}$ & 1.57 & $\begin{array}{c}.026(.386) \\
{[-.282, .419]}\end{array}$ & 1.57 & $\begin{array}{l}.094(1.402) \\
{[-.085 ; .502]}\end{array}$ & 1.58 & $\begin{array}{c}.023(.333) \\
{[-.292 ; .410]}\end{array}$ & 1.58 \\
\hline Machinery and Equipment Parts & $\begin{array}{c}.005(.077) \\
{[-.318, .344]}\end{array}$ & 1.48 & $\begin{array}{l}.012(.185) \\
{[-.306, .370]}\end{array}$ & 1.48 & $\begin{array}{l}.006(.092) \\
{[-.316, .347]}\end{array}$ & 1.48 & $\begin{array}{l}.004(.057) \\
{[-.400, .424]}\end{array}$ & 1.48 & $\begin{array}{l}-.004(-.054) \\
{[-.407, .386]}\end{array}$ & 1.48 & $\begin{array}{l}-.003(-.045) \\
{[-.407, .388]}\end{array}$ & 1.48 & $\begin{array}{l}.006(.097) \\
{[-.316 ; .349]}\end{array}$ & 1.48 & $\begin{array}{l}-.001(-.015) \\
{[-.401 ; .395]}\end{array}$ & 1.48 \\
\hline Construction Products & $\begin{array}{l}-.020(-.307) \\
{[-.385, .281]}\end{array}$ & 1.46 & $\begin{array}{l}-.019(-.283) \\
{[-.390, .292]}\end{array}$ & 1.46 & $\begin{array}{l}-.022(-.348) \\
{[-.393, .275]}\end{array}$ & 1.46 & $\begin{array}{l}-.071(-1.040) \\
{[-.632, .195]}\end{array}$ & 1.46 & $\begin{array}{l}-.052(-.789) \\
{[-.560, .240]}\end{array}$ & 1.46 & $\begin{array}{l}-.052(-.782) \\
{[-.560, .242]}\end{array}$ & 1.46 & $\begin{array}{l}-.023(-.355) \\
{[-.396 ; .275]}\end{array}$ & 1.47 & $\begin{array}{l}-.055(-.829) \\
{[-.570 ; .233]}\end{array}$ & 1.47 \\
\hline Automobile Parts & $\begin{array}{l}-.028(-.441) \\
{[-.422, .268]}\end{array}$ & 1.43 & $\begin{array}{l}-.024(-.364) \\
{[-.417, .287]}\end{array}$ & 1.43 & $\begin{array}{l}-.030(-.472) \\
{[-.428, .263]}\end{array}$ & 1.43 & $\begin{array}{c}.034(.506) \\
{[-.318, .539]}\end{array}$ & 1.43 & $\begin{array}{c}.048(.742) \\
{[-.258, .569]}\end{array}$ & 1.43 & $\begin{array}{c}.049(.749) \\
{[-.257, .572]}\end{array}$ & 1.43 & $\begin{array}{l}-.031(-.485) \\
{[-.434 ; .262]}\end{array}$ & 1.45 & $\begin{array}{c}.043(.653) \\
{[-.278 ; .554]}\end{array}$ & 1.45 \\
\hline Consumer Products & $\begin{array}{c}.038(.550) \\
{[-.202, .358]}\end{array}$ & 1.66 & $\begin{array}{c}.035(.499) \\
{[-.213, .358]}\end{array}$ & 1.66 & $\begin{array}{c}.037(.545) \\
{[-.203, .358]}\end{array}$ & 1.66 & $\begin{array}{l}.086(1.179) \\
{[-.140, .556]}\end{array}$ & 1.66 & $\begin{array}{l}.088(1.259) \\
{[-.121, .549]}\end{array}$ & 1.66 & $\begin{array}{l}.088(1.253) \\
{[-.122, .550]}\end{array}$ & 1.66 & $\begin{array}{c}.037(.529) \\
{[-.206 ; .357]}\end{array}$ & 1.67 & $\begin{array}{l}.083(1.176) \\
{[-.136 ; .538]}\end{array}$ & 1.67 \\
\hline Firm Size & $\begin{array}{l}-.100(-1.724) \\
{[-.121, .008]}\end{array}$ & 1.18 & $\begin{array}{l}-.090(-1.520) \\
{[-.118, .015]}\end{array}$ & 1.19 & $\begin{array}{l}-.095(-1.633) \\
{[-.119, .011]}\end{array}$ & 1.19 & $\begin{array}{l}-.125(-2.033)^{*} \\
{[-.164,-.003]}\end{array}$ & 1.18 & $\begin{array}{c}-.156(-2.625)^{* * *} \\
{[-.182,-.026]}\end{array}$ & 1.19 & $\begin{array}{l}-.156(-2.612)^{*} \\
{[-.182,-.025]}\end{array}$ & 1.19 & $\begin{array}{l}-.095(-1.628) \\
{[-.120 ; .011]}\end{array}$ & 1.19 & $\begin{array}{l}-.155(-2.605)^{*} \\
{[-.182 ;-.025]}\end{array}$ & 1.19 \\
\hline Firm Age & $\begin{array}{l}-.039(-.695) \\
{[-.088, .042]}\end{array}$ & 1.10 & $\begin{array}{l}-.037(-.640) \\
{[-.088, .045]}\end{array}$ & 1.10 & $\begin{array}{l}-.039(-.696) \\
{[-.089, .042]}\end{array}$ & 1.10 & $\begin{array}{c}.039(.659) \\
{[-.054, .108]}\end{array}$ & 1.10 & $\begin{array}{c}.040(.693) \\
{[-.051, .106]}\end{array}$ & 1.10 & $\begin{array}{c}.040(.695) \\
{[-.051, .106]}\end{array}$ & 1.10 & $\begin{array}{l}-.039(-.692) \\
{[-.089 ; .043]}\end{array}$ & 1.10 & $\begin{array}{c}.041(.710) \\
{[-.050 ; .107]}\end{array}$ & 1.10 \\
\hline Competitive Intensity & $\begin{array}{l}-.018(-.317) \\
{[-.104, .075]}\end{array}$ & 1.14 & $\begin{array}{c}.002(.041) \\
{[-.090, .093]}\end{array}$ & 1.13 & $\begin{array}{l}-.022(-.376) \\
{[-.108, .073]}\end{array}$ & 1.15 & $\begin{array}{l}.140(2.316)^{*} \\
{[.020, .243]}\end{array}$ & 1.14 & $\begin{array}{c}.162(2.805) * * \\
{[.045, .260]}\end{array}$ & 1.13 & $\begin{array}{c}.165(2.812)^{* * *} \\
{[.046, .263]}\end{array}$ & 1.15 & $\begin{array}{l}-.021(-.367) \\
{[-.108 ; .074]}\end{array}$ & 1.15 & $\begin{array}{l}.167(2.853)^{* *} \\
{[.049 ; .266]}\end{array}$ & 1.15 \\
\hline Market Turbulence & $\begin{array}{c}.039(.642) \\
{[-.057, .112]}\end{array}$ & 1.29 & $\begin{array}{c}.033(.535) \\
{[-.063, .110]}\end{array}$ & 1.29 & $\begin{array}{c}.038(.620) \\
{[-.058, .111]}\end{array}$ & 1.29 & $\begin{array}{c}-.185(-2.879) * * \\
{[-.258,-.048]}\end{array}$ & 1.29 & $\begin{array}{c}-.176(-2.836 * * * \\
{[-.247,-.044]}\end{array}$ & 1.29 & $\begin{array}{c}-.176(-2.836)^{* *} \\
{[-.247,-.045]}\end{array}$ & 1.29 & $\begin{array}{c}.037(.611) \\
{[-.059 ; .111]}\end{array}$ & 1.30 & $\begin{array}{c}-.178(-2.871)^{* * *} \\
{[-.250 ;-.046]}\end{array}$ & 1.30 \\
\hline Technology Turbulence & $\begin{array}{l}.089(1.532) \\
{[-.019, .150]}\end{array}$ & 1.19 & $\begin{array}{l}.082(1.389) \\
{[-.025, .147]}\end{array}$ & 1.19 & $\begin{array}{l}.087(1.499) \\
{[-.020, .149]}\end{array}$ & 1.19 & $\begin{array}{c}.061(.989) \\
{[-.052, .157]}\end{array}$ & 1.19 & $\begin{array}{l}.073(1.237) \\
{[-.038, .164]}\end{array}$ & 1.19 & $\begin{array}{l}.073(1.227) \\
{[-.038, .164]}\end{array}$ & 1.19 & $\begin{array}{c}.088(1.504) \\
{[-.020 ; .150]}\end{array}$ & 1.20 & $\begin{array}{l}.079(1.324) \\
{[-.033 ; .170]}\end{array}$ & 1.20 \\
\hline $\begin{array}{l}\text { Information Technology } \\
\text { Assimilation }\end{array}$ & & & & & & & & & & & & & $\begin{array}{c}.009(.161) \\
{[-.073 ; .087]}\end{array}$ & 1.12 & $\begin{array}{c}.054(.932) \\
{[-.050 ; .141]}\end{array}$ & 1.12 \\
\hline Contextual Ambidexterity & $\begin{array}{c}.415(6.981)^{* * * *} \\
{[.051, .091]}\end{array}$ & 1.25 & $\begin{array}{c}.386(6.044) * * * \\
{[.044, .087]}\end{array}$ & 1.38 & $\begin{array}{c}.403(6.405)^{* * * *} \\
{[.048, .090]}\end{array}$ & 1.39 & $\begin{array}{l}.159(2.523)^{*} \\
{[.007, .057]}\end{array}$ & 1.25 & $\begin{array}{c}.248(3.881)^{* * * *} \\
{[.024, .075]}\end{array}$ & 1.38 & $\begin{array}{c}.247(3.838)^{* * * * *} \\
{[.024, .075]}\end{array}$ & 1.39 & $\begin{array}{c}.401(6.270)^{* * * *} \\
{[.047 ; .090]}\end{array}$ & 1.43 & $\begin{array}{c}.236(3.621) * * * \\
{[.022 ; .073]}\end{array}$ & 1.43 \\
\hline Knowledge Breadth (KB) & $\begin{array}{c}.219(3.849)^{* * * *} \\
{[.090, .279]}\end{array}$ & 1.15 & $\begin{array}{c}.259(4.452)^{* * * *} \\
{[.122, .315]}\end{array}$ & 1.15 & $\begin{array}{c}.226(3.891)^{* * * *} \\
{[.094, .286]}\end{array}$ & 1.19 & $\begin{array}{c}.159(2.621)^{* * *} \\
{[.039, .274]}\end{array}$ & 1.15 & $\begin{array}{l}.110(1.885) \\
{[-.005, .222]}\end{array}$ & 1.15 & $\begin{array}{l}.113(1.901) \\
{[-.004, .227]}\end{array}$ & 1.19 & $\begin{array}{c}.225(3.836)^{* * * *} \\
{[.092 ; .286]}\end{array}$ & 1.20 & $\begin{array}{l}.106(1.777) \\
{[-.011 ; .221]}\end{array}$ & 1.20 \\
\hline Knowledge Depth (KD) & $\begin{array}{c}.092(1.541) \\
{[-.021, .171]}\end{array}$ & 1.25 & $\begin{array}{l}.113(1.870) \\
{[-.005, .190]}\end{array}$ & 1.24 & $\begin{array}{l}.092(1.537) \\
{[-.021, .171]}\end{array}$ & 1.25 & $\begin{array}{c}.301(4.769)^{* * * *} \\
{[.170, .408]}\end{array}$ & 1.25 & $\begin{array}{c}.300(4.963) * * * \\
{[.174, .402]}\end{array}$ & 1.24 & $\begin{array}{c}.302(4.954) * * * \\
{[.175, .405]}\end{array}$ & 1.25 & $\begin{array}{c}.091(1.525) \\
{[-.022 ; .171]}\end{array}$ & 1.25 & $\begin{array}{c}.300(4.906) * * * \\
{[.172 ; .403]}\end{array}$ & 1.25 \\
\hline Contextual Ambidexterity x KB & $\begin{array}{c}.179^{\mathrm{a}}(3.207) * * \\
{[.012, .049]}\end{array}$ & 1.09 & & & $\begin{array}{c}.180^{c}(3.220)^{* * *} \\
{[.012, .049]}\end{array}$ & 1.10 & $\begin{array}{l}-.009(-.147)^{\mathrm{e}} \\
{[-.025, .021]}\end{array}$ & 1.09 & & & $\begin{array}{l}-.016^{\mathrm{g}}(-.280) \\
{[-.025, .019]}\end{array}$ & 1.10 & $\begin{array}{c}.180(3.213)^{* * *} \\
{[.012 ; .049]}\end{array}$ & 1.10 & $\begin{array}{l}-.016(-.283) \\
{[-.025 ; .019]}\end{array}$ & 1.10 \\
\hline Contextual Ambidexterity x KD & & & $\begin{array}{l}-.030^{\mathrm{b}}(-.505) \\
{[-.022, .013]}\end{array}$ & 1.18 & $\begin{array}{l}-.035^{\mathrm{d}}(-.612) \\
{[-.023, .012]}\end{array}$ & 1.18 & & & $\begin{array}{c}.251^{\mathrm{f}}(4.244)^{* * * *} \\
{[.024, .066]}\end{array}$ & 1.18 & $\begin{array}{c}.251^{\mathrm{h}}(4.242)^{* * * *} \\
{[.024, .066]}\end{array}$ & 1.18 & $\begin{array}{l}-.036(-.623) \\
{[-.023 ; .012]}\end{array}$ & 1.19 & $\begin{array}{c}.246(4.138)^{* * * *} \\
{[.023 ; .065]}\end{array}$ & 1.19 \\
\hline$\overline{\text { F-Value }}$ & 8.545 & & 7.507 & & 7.979 & & 5.723 & & 7.449 & & 6.930 & & 7.451 & & 6.548 & \\
\hline P-Val & .000 & & .000 & & .00 & & .000 & & .000 & & .000 & & .000 & & .000 & \\
\hline & .339 & & .311 & & .340 & & .256 & & .309 & & .309 & & .340 & & .312 & \\
\hline Adjusted R-Square & .299 & & .270 & & .297 & & .211 & & .267 & & .264 & & .295 & & .264 & \\
\hline
\end{tabular}

Note: *** $\mathrm{p}<0.001 ; * * \mathrm{p}<0.010 ; * \mathrm{p}<0.050 ; \mathrm{VIF}=$ Variance Inflation Factors

$\Delta$ (increased) $\mathrm{R}$-square due to interactions and $\mathrm{F}$-tests: $\mathrm{a}=\left(\Delta \mathrm{R}^{2}=.032 ; \mathrm{F}=11.048^{* *}\right) ; \mathrm{b}=\left(\Delta \mathrm{R}^{2}=.001 ; \mathrm{F}=.024\right) ; \mathrm{c}=\left(\Delta \mathrm{R}^{2}=.030 ; \mathrm{F}=10.368^{* *}\right) ; \mathrm{d}=\left(\Delta \mathrm{R}^{2}=.001 ; \mathrm{F}=.374\right) ; \mathrm{e}=\left(\Delta \mathrm{R}^{2}=.001 ; \mathrm{F}=.094\right) ; \mathrm{f}=\left(\Delta \mathrm{R}^{2}=.057 ; \mathrm{F}=18.594 * * *\right) ;$ $\mathrm{g}=\left(\Delta \mathrm{R}^{2}=.001 ; \mathrm{F}=.078\right) . \mathrm{h}=\left(\Delta \mathrm{R}^{2}=.056 ; \mathrm{F}=17.992^{* * *}\right)$. 
Figure 2: Graphical Representation - Moderating Effects
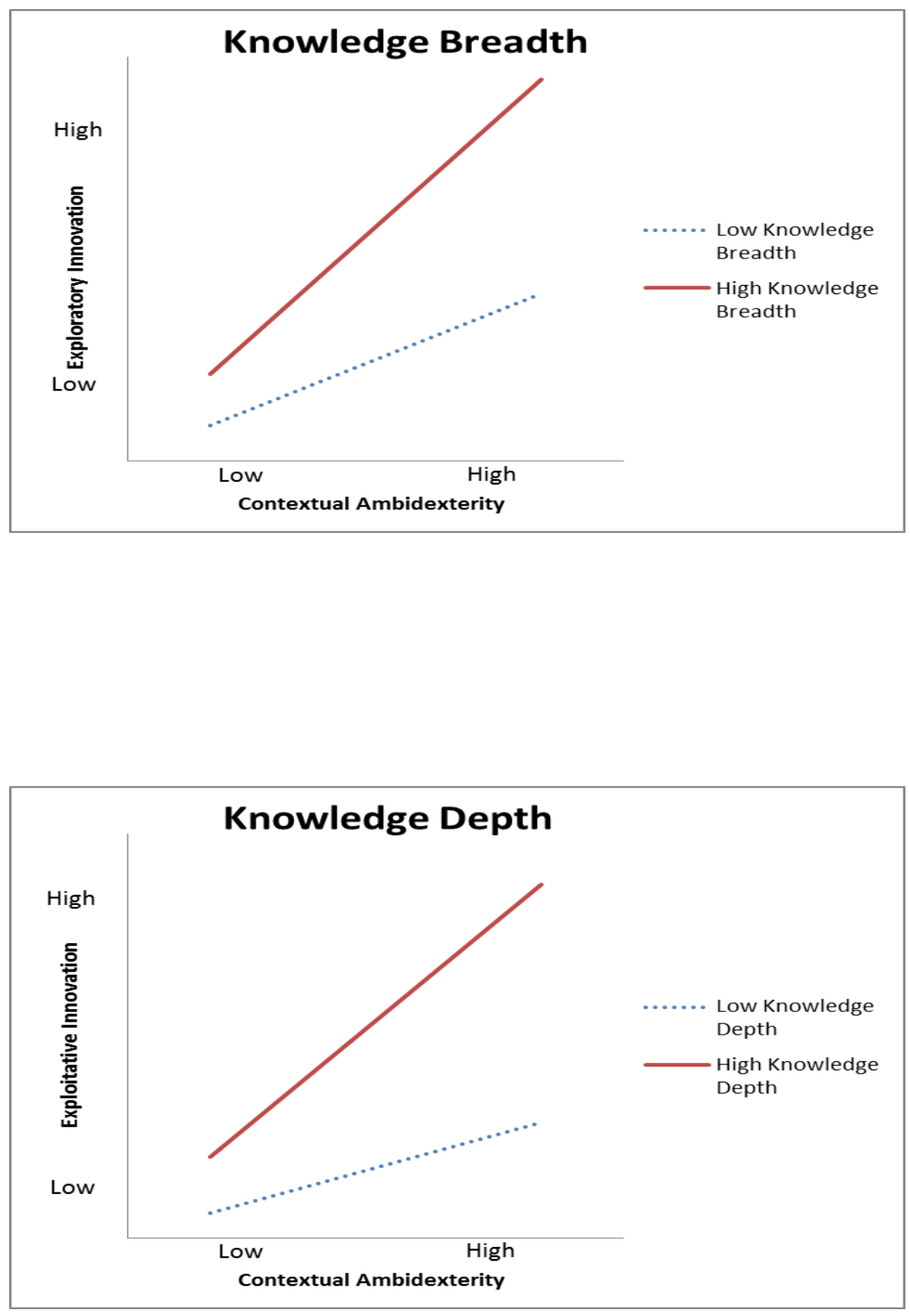
Table 3: Post-Hoc Path Analysis

\begin{tabular}{|c|c|c|c|c|}
\hline \multirow[b]{2}{*}{ Path Relationship } & Model 18 & Model 19 & Model 20 & Model 21 \\
\hline & & & & \\
\hline Electronic Goods $\rightarrow$ Exploratory Innovation & $.098(1.409)$ & $.094(1.352)$ & $.094(1.466)$ & $.094(1.457)$ \\
\hline Electronic Goods $\rightarrow$ Exploitative Innovation & $.058(.788)$ & $.049(.668)$ & $.026(.399)$ & $.023(.346)$ \\
\hline Electronic Goods $\rightarrow$ Contextual Ambidexterity (CA) & $.005(.072)$ & $.005(.072)$ & & $.002(.024)$ \\
\hline Machinery and Equipment Parts $\rightarrow$ Exploratory Innovation & $.012(.184)$ & $.014(.210)$ & $.006(.095)$ & $.006(.101)$ \\
\hline Machinery and Equipment Parts $\rightarrow$ Exploitative Innovation & $-.005(-.072)$ & $-.001(-.017)$ & $-.003(-.047)$ & $-.001(-.016)$ \\
\hline Machinery and Equipment Parts $\rightarrow \mathrm{CA}$ & $-.072(-.995)$ & $-.072(-.995)$ & & $-.038(-.594)$ \\
\hline Construction Products $\rightarrow$ Exploratory Innovation & $.009(.127)$ & $.005(.077)$ & $-.022(-.361)$ & $-.023(-.369)$ \\
\hline Construction Products $\rightarrow$ Exploitative Innovation & $-.040(-.557)$ & $-.047(-.669)$ & $-.051(-.812)$ & $-.055(-.861)$ \\
\hline Construction Products $\rightarrow \mathrm{CA}$ & $-.038(-.525)$ & $-.038(-.525)$ & & $-.073(-1.141)$ \\
\hline Automobile Parts $\rightarrow$ Exploratory Innovation & $-.007(-.107)$ & $-.013(-.200)$ & $-.030(-.492)$ & $-.031(-.508)$ \\
\hline Automobile Parts $\rightarrow$ Exploitative Innovation & $.027(.380)$ & $.013(.185)$ & $.048(.781)$ & $.043(.683)$ \\
\hline Automobile Parts $\rightarrow$ CA & $-.085(-1.203)$ & $-.085(-1.203)$ & & $-.073(-1.153)$ \\
\hline Consumer Products $\rightarrow$ Exploratory Innovation & $.035(.491)$ & $.030(.424)$ & $.037(.566)$ & $.037(.551)$ \\
\hline Consumer Products $\rightarrow$ Exploitative Innovation & $.108(1.429)$ & $.097(1.294)$ & $.087(1.300)$ & $.083(1.223)$ \\
\hline Consumer Products $\rightarrow \mathrm{CA}$ & $-.077(-.999)$ & $-.077(-.999)$ & & $-.085(-1.234)$ \\
\hline Firm Size $\rightarrow$ Exploratory Innovation & $-.067(-1.116)$ & $-.068(-1.135)$ & $-.094(-1.710)$ & $-.095(-1.707)$ \\
\hline Firm Size $\rightarrow$ Exploitative Innovation & $-.086(-1.357)$ & $-.088(-1.403)$ & $-.154(-2.735)^{* *}$ & $-.155(-2.731)^{* *}$ \\
\hline Firm Size $\rightarrow$ CA & $.043(.669)$ & $.043(.669)$ & & $.047(.822)$ \\
\hline Firm Age $\rightarrow$ Exploratory Innovation & $-.049(-.843)$ & $-.048(-.826)$ & $-.039(-.724)$ & $-.039(-.721)$ \\
\hline Firm Age $\rightarrow$ Exploitative Innovation & $.003(.052)$ & $.006(.092)$ & $.039(.724)$ & $.041(.740)$ \\
\hline Firm Age $\rightarrow$ CA & $.003(.047)$ & $.003(.047)$ & & $.031(.554)$ \\
\hline Competitive Intensity $\rightarrow$ Exploratory Innovation & $.046(.790)$ & $.048(.824)$ & $-.021(-.399)$ & $-.021(-.387)$ \\
\hline Competitive Intensity $\rightarrow$ Exploitative Innovation & $.181(2.934)^{* *}$ & $.185(3.025)^{* *}$ & $.163(2.982)^{* *}$ & $.167(3.009)^{* *}$ \\
\hline Competitive Intensity $\rightarrow$ CA & $-.088(-1.412)$ & $-.088(-1.412)$ & & $-.117(-2.100)^{*}$ \\
\hline Market Turbulence $\rightarrow$ Exploratory Innovation & $.028(.437)$ & $.026(.408)$ & $.037(.654)$ & $.037(.635)$ \\
\hline Market Turbulence $\rightarrow$ Exploitative Innovation & $-.171(-2.570)^{*}$ & $-.175(-2.650)^{* *}$ & $-.174(-2.992) * *$ & $-.178(-2.982)^{* *}$ \\
\hline Market Turbulence $\rightarrow \mathrm{CA}$ & $-.193(-2.908)^{* *}$ & $-.193(-2.908)^{* *}$ & & $-.181(-3.048)^{* *}$ \\
\hline Technology Turbulence $\rightarrow$ Exploratory Innovation & $.115(1.909)$ & $.121(2.004)^{*}$ & $.086(1.565)$ & $.088(1.576)$ \\
\hline Technology Turbulence $\rightarrow$ Exploitative Innovation & $.087(1.370)$ & $.100(1.576)$ & $.072(1.281)$ & $.079(1.387)$ \\
\hline Technology Turbulence $\rightarrow \mathrm{CA}$ & $-.077(-1.199)$ & $-.077(-1.199)$ & & $-.094(-1.625)$ \\
\hline Information Technology Assimilation (ITA) $\rightarrow$ CA & $.280(4.558)^{* * *}$ & $.191(3.194)^{* *}$ & & $.152(2.852)^{* *}$ \\
\hline $\mathrm{CA} \rightarrow$ Exploratory Innovation & $.475(8.157)^{* * *}$ & $.464(7.829)^{* * *}$ & $.398(7.036)^{* * *}$ & $.399(6.483)^{* * *}$ \\
\hline $\mathrm{CA} \rightarrow$ Exploitative Innovation & $.191(3.194)^{* *}$ & $.257(4.123)^{* * *}$ & $.244(4.216)^{* * *}$ & $.235(3.744)^{* * *}$ \\
\hline ITA $\rightarrow$ Exploratory Innovation & & $.053(.929)$ & & $.009(.174)$ \\
\hline ITA $\rightarrow$ Exploitative Innovation & & $.118(1.976)$ & & $.054(1.005)$ \\
\hline Knowledge Breadth $(\mathrm{KB}) \rightarrow$ Exploratory Innovation & & & $.224(4.101)^{* * *}$ & $.225(4.083)^{* * *}$ \\
\hline $\mathrm{KB} \rightarrow$ Exploitative Innovation & & & $.112(2.004) *$ & $.106(1.891)$ \\
\hline Knowledge Depth $(\mathrm{KD}) \rightarrow$ Exploratory Innovation & & & $.091(1.658)$ & $.091(1.648)$ \\
\hline $\mathrm{KD} \rightarrow$ Exploitative Innovation & & & $.299(5.345)^{* * *}$ & $.299(5.301)^{* * *}$ \\
\hline $\mathrm{CA} \times \mathrm{KB} \rightarrow$ Exploratory Innovation & & & $.178(3.361)^{* * *}$ & $.180(3.367)^{* * *}$ \\
\hline $\mathrm{CA} \times \mathrm{KB} \rightarrow$ Exploitative Innovation & & & $-.016(-.292)$ & $-.016(-.297)$ \\
\hline $\mathrm{CA} \times \mathrm{KD} \rightarrow$ Exploratory Innovation & & & $-.035(-.648)$ & $-.036(-.654)$ \\
\hline CA $x$ KD $\rightarrow$ Exploitative Innovation & & & $.249(4.493)^{* * *}$ & $.246(4.347)^{* * *}$ \\
\hline Chi-Square $\left(X^{2}\right)$ & 29.320 & 24.779 & 83.420 & 73.720 \\
\hline Degree of Freedom $(d f)$ & 13 & 11 & 51 & 55 \\
\hline$X^{2} / d f$ & 2.255 & 2.253 & 1.636 & 1.340 \\
\hline p-value & .006 & .010 & .003 & .047 \\
\hline Comparative fit index (CFI) & .955 & .962 & .936 & .964 \\
\hline Root mean square error of approximation (RMSEA) & .071 & .071 & .051 & .037 \\
\hline
\end{tabular}

Note:

$* * * \mathrm{p}<0.001 ; * * \mathrm{p}<0.010 ; * \mathrm{p}<0.050$

Standardized Coefficients are reported with t-value in parentheses 


\section{Appendix 1: Measurement and Factor Loading}

Information Technology Assimilation ( $\mathrm{CR}=.918 ; \mathrm{AVE}=.789)$

We can implement IT (information technology) in many business processes.

We can implement IT in a large number of functional areas.

The extent to which IT is used in our business processes (e.g., operation, management, and decision making) is high. .859

Alignment $(\mathrm{CR}=.813 ; \mathrm{AVE}=.592)$

The management systems in this company work coherently to support the overall objectives of the company. .806

People in this company work toward the same goals because our management systems avoid conflicting objectives. .775

The management systems in this company prevent us from wasting resources on unproductive activities. .726

Adaptability $(\mathrm{CR}=.807, \mathrm{AVE}=.583)$

The management systems in this company encourage people to challenge outmoded practices (traditions).

The management systems in this company are flexible enough to allow us to respond quickly to changes in our market.

The management systems in this organization evolve rapidly in response to shifts in our business priorities. .776

Knowledge Breadth $(\mathrm{CR}=.837$; AVE $=.632)$

We possess market information from a diversified customer portfolio. .754

We have accumulated knowledge of multiple market segments.

Our research and development expertise consists of knowledge from a variety of backgrounds. .820

Knowledge Depth $(\mathrm{CR}=.762, \mathrm{AVE}=.516)$

We have a thorough understanding and experience of current customers. .691

We have acquired a great deal of experience about this industry. .703

The knowledge of our firm in this industry is thorough.

We have in-depth knowledge about the technology in this industry. .760

Exploratory Innovation $(\mathrm{CR}=.836, \mathrm{AVE}=.631)$

We always accept demands that go beyond existing products and services. .848

We regularly approach new opportunities in new markets.

We regularly experiment with new products and services in existing markets. .741

We commercialize products and services that are completely new to our organization.

Exploitative Innovation $(\mathrm{CR}=.802, \mathrm{AVE}=.575)$

We frequently make small adjustments to our existing products and services.

We continuously improve the efficiency of the creation of products or services.

We perpetually reduce the costs of the creation of goods or services without quality loss.

We continuously increase the levels of automation in the creation of goods or services. .722

* Factor loadings are standardized

--- Items deleted due to low factor loading

$\mathrm{CR}=$ Composite Reliability, AVE $=$ Average Variance Extracted 


\section{Appendix 2: Cross Loading Analysis}

1. Information Technology Assimilation
We can implement IT (information technology) in many business processes.
We can implement IT in a large number of functional areas.

We can implement IT in a large number of functional areas.

The extent to which IT is used in our business processes (e.g., operation, management, and decision making) is high.

\begin{tabular}{|l|}
\hline 1 \\
\hline .922 \\
.922 \\
.901 \\
\hline
\end{tabular}

2

\section{Alignmen}

The management systems in this company work coherently to support the overall objectives of the company.

People in this company work toward the same goals because our management systems avoid conflicting objectives.

The management systems in this company prevent us from wasting resources on unproductive activities.

\begin{tabular}{|c|c|c|c|c|c|c|}
\hline .056 & .744 & .248 & .053 & .193 & .217 & .075 \\
\hline .049. & .820 & .198 & -.068 & .106 & .170 & -.003 \\
\hline .026. & .831 & .156 & .130 & .028 & .070 & . 101 \\
\hline .022 & .274 & .768 & -.102 & -.025 & .163 & .174 \\
\hline . 116 & .144 & .813 & .088 & .100 & .190 & .018 \\
\hline . 133 & .191 & .812 & .095 & .132 & .067 & .101 \\
\hline .077. & -.059 & .049 & .818 & .017 & .127 & .208 \\
\hline .073. & .153 & .001 & .853 & .068 & .173 & -.020 \\
\hline .051 & .018 & .037 & .858 & .139 & .092 & .087 \\
\hline .078. & .015 & .051 & .106 & $\begin{array}{l}.789 \\
\end{array}$ & .030 & .161 \\
\hline .036. & .154 & .068 & .066 & .817 & .060 & .034 \\
\hline .013. & .104 & .074 & .042 & .768 & .170 & .227 \\
\hline .089. & .231 & .174 & .166 & .236 & .763 & .091 \\
\hline .051 & .160 & .118 & .127 & .017 & .829 & .151 \\
\hline-.001 & .084 & .136 & .142 & .067 & .839 & .109 \\
\hline .115 & .072 & .137 & .120 & .135 & .076 & .821 \\
\hline . 102 & .203 & .042 & .005 & .145 & .057 & .827 \\
\hline-.032 & -.109 & .093 & .169 & .163 & .229 & .766 \\
\hline
\end{tabular}

\section{Adaptability}

The management systems in this company encourage people to challenge outmoded practices (traditions).

The management systems in this company are flexible enough to allow us to respond quickly to changes in our market.

The management systems in this organization evolve rapidly in response to shifts in our business priorities.

2

025

3

4

$.025 \quad .103$

.007

5

7

\section{Knowledge Breadth}

We possess market information from a diversified customer portfolio.

We have accumulated knowledge of multiple market segments.

Our research and development expertise consists of knowledge from a variety of backgrounds.

.001

.094

.081

.007

.005

.042

.089

\section{Knowledge Depth}

We have a thorough understanding and experience of current customers.

We have acquired a great deal of experience about this industry.

We have in-depth knowledge about the technology in this industry.

\section{Exploratory Innovation}

We always accept demands that go beyond existing products and services.

We regularly approach new opportunities in new markets.

We regularly experiment with new products and services in existing markets.

\section{Exploitative Innovation}

We continuously improve the efficiency of the creation of products or services.

We perpetually reduce the costs of the creation of goods or services without quality loss.

We continuously increase the levels of automation in the creation of goods or services.

Note:

Principal Component Analysis with varimax rotation

Kaiser-Meyer-Olkin (KMO) test: $\mathrm{KMO}=.803$

Bartlett's Test of Sphericity: Approx. chi-square $=2523.122 ; d f=210 ; \mathrm{p}<0.001)$ 


\section{Appendix 3: Hierarchical Regression Model}

Electronic Goods

Machinery and Equipment Parts

Construction Products

Automobile Parts

Consumer Products

Firm Size

Firm Age

Competitive Intensity

Market Turbulence

Technology Turbulence

Information Technology Assimilation residual

Contextual Ambidexterity

Knowledge Breadthresidual

Knowledge Depth $\mathrm{h}_{\text {residual }}$

Contextual Ambidexterity x Knowledge Breadth residual

Contextual Ambidexterity x Knowledge Depth residual

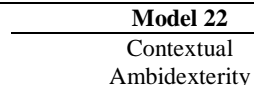

Model 23
Exploratory
Innovation

$.011(.144)$

$[-1.823,2.111]$

$-.075(-1.006)$

$[-3.366,1.090]$

$-.032(-.440)$

$[-2.742,1.741]$

$-.079(-1.087)$

$[-3.594,1.038]$

$-.072(-.916)$

$[-2.757,1.007]$

$.047(.716)$

$[-.276, .591]$

$.001(.004)$

$[-.436, .438]$

$-.087(-1.361)$

$[-1.006, .184]$

$-194(-2.844)^{* *}$

$[-1.363,-.248]$

$-.081(-1.215)$

$[-.918, .218]$

$.138(2.197)^{*}$

[.061, 1.121]

VIF
1.565

1.469

1.446

1.414

1.651

1.159

1.159

1.081

1.096

1.236

1.182

1.182

1.047
Innovation

[-.070, .509]

$.003(.051)$

$[-.320, .337]$

$-.021(-.331)$

$[-.386, .275]$

$-.026(-.407)$

$[-.413, .272]$

$.041(.607)$

$[-.192, .363]$

$-.105(-1.823)$

$[-.124, .005]$

$-.037(-.662)$

$[-.086, .043]$

$-.023(-.399)$

$[-.108, .071]$

$.032(.537)$

[-.061, .107]

$.089(1.549)$

$[-.018, .149]$

$457(8.158)^{* * *}$

[.059, .097]

Model 24
Exploitative
Innovation

\begin{tabular}{ccc} 
& \multicolumn{3}{c}{ Innovation } \\
VIF & & VIF \\
1.570 & $.034(.502)$ & 1.570
\end{tabular}

$[-.261, .440]$

$1.479 \quad-.002(-.030)$

$[-.404, .392]$

$1.459 \quad-.057(-.858)$

$[-.575, .226]$

$1.432 \quad .051(.784)$

$[-.250, .580]$

$1.664 \quad .092(1.307)$

$[-.113, .559]$

$1.194-.156(-2.608) *$

$[-.182,-.025]$

$1.100 \quad .044(.762)$

$[-.048, .109]$

$.160(2.734)^{* * *}$

$[.042, .259]$

$1.291-.189(-3.050)^{* *}$

$[-.259,-.056]$

$.069(1.161)$

$[-.042, .161]$

$1.129 \quad .305(5.255)^{* * *}$
$[.038, .084]$

$.305(5.255)^{* *}$
$[.038, .084]$

VIF
1.570

1.479

1.459

1.432

1.664

1.194

1.100

1.151

1.291

1.129

\begin{tabular}{|c|c|c|c|}
\hline $.208(3.692)^{* * *}$ & 1.138 & $.119(2.043) *$ & 1.138 \\
\hline$[.083, .272]$ & & {$[.004, .233]$} & \\
\hline $.080(1.416)$ & 1.149 & $.284(4.855)^{* * *}$ & 1.149 \\
\hline$[-.027, .164]$ & & {$[.169, .400]$} & \\
\hline $.215(3.877)^{* * *}$ & 1.101 & $-.027(-.476)$ & 1.101 \\
\hline$[.017, .053]$ & & {$[-.027, .017]$} & \\
\hline $.036(.655)$ & 1.083 & $.238(4.186)^{* * *}$ & 1.083 \\
\hline$[-.012, .024]$ & & {$[.024, .068]$} & \\
\hline
\end{tabular}

\begin{tabular}{lccc} 
F-Value & 2.676 & 8.477 & 6.892 \\
P-Value & .003 & .000 & .000 \\
R-Square & .111 & .354 & .308 \\
Adjusted R-Square & .069 & .312 & .264 \\
\hline
\end{tabular}

Adjusted R-Square

ation Factors

Note: $* * * \mathrm{p}<0.001 ; * * \mathrm{p}<0.010 ; * \mathrm{p}<0.050 ; \mathrm{VIF}=$ Variance Inflation Factors
Standardized Coefficients are reported with (t-value) in parentheses and $95 \%$ confidence interval in the brackets [lower bound, upper bound]

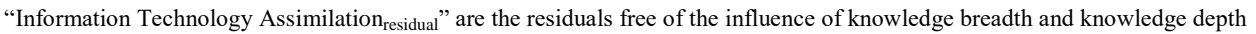

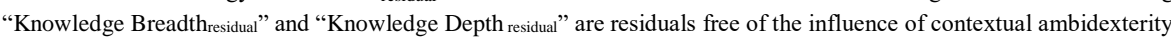




\section{Endnote}

\footnotetext{
${ }^{1}$ IT assets are a set of technological resources, including platform technologies (hardware and operating systems), network and telecommunication technologies, databases and a variety of software and shared services, and so on, that provides the foundation for present and future IT use (Armstrong and Sambamurthy, 1999; Liu et al., 2016).

${ }^{2}$ Previous studies uses different dualities to capture the ambidexterity, such as exploratory-exploitation (e.g. Patel et al., 2013), efficiency and flexibility (e.g. Adler et al., 1999), and alignment-adaptability (e.g. Gibson and Birkinshaw, 2004). This study employs the alignmentadaptability duality. This is widely used in the ambidexterity studies that focus on capturing firms' managerial capability to deal with the conflicting demands arising from the simultaneous need to coordinate the internal activities to support the overall organizational objectives and reconfigure the business processes to meet changes in the environment (De Clercq et al., 2014; De Clercq et al., 2013; Gibson and Birkinshaw, 2004), which is more in line with the focus of this study.

${ }^{3}$ Differing from the "general" use of IT, IT assimilation represents a more "sophisticated" use of IT in supporting business strategies. More specifically, "not only does it refer to the extent to which IT has been infused into specific business activities, but also how effectively IT is enabling the conduct of those activities relative to rival" (Armstrong and Sambamurthy, 1999: 305).

${ }^{4}$ Two related streams of research have emerged to examine both types of innovation in a single study. The first focuses on innovation ambidexterity, and examines the factors that enable firms to pursue exploratory and exploitative innovation simultaneously (e.g. Kortmann, 2015). The second stream differentiates between these two types of innovation and examines the factors that enable firms to develop different innovation activities (e.g. Limaj et al., 2016). This study is in line with this second literature stream.

${ }^{5}$ In the recent ambidexterity literature, researchers have differentiated the ambidexterity phenomena according to different domains of activities. For example, Gibson and Birkinshaw (2004) study firms' ambidexterity with regard to a managerial capacity. He and Wong (2004) study firms' ambidexterity in pursuit of innovation strategy. Recently, several researchers took a step further to study the relationship between different ambidexterity domains. For example, Kortmann (2015) investigated the relationship between ambidexterity-oriented decisions and innovative ambidexterity. This study examines the relationship between firms' ambidexterity with regard to managerial capacity - CA (Gibson and Birkinshaw, 2004) and two types of innovation activities - exploratory/exploitative innovation (Kollmann and Stöckmann, 2014). This study did not follow Kortmann (2015)'s approach to form a higher order construct (innovation ambidexterity) by combining exploratory innovation with exploitative innovation. In order to gain a more comprehensive understanding on how different dimensions of knowledge base may influence CA-exploratory innovation and CA-exploitative innovation association, which in turn affecting indirect IT assimilation-CA-exploratory/exploitative innovation relationship. This study's approach is closer to the recent studies on examining the relationship between two different ambidexterity domains.

${ }^{6}$ This study only includes items retained from the earlier analysis (see Appendix 1) to assess the formation and analysis of the constructs in the correlation table (see Table 1).

${ }^{7}$ The level is between 1 and 5 because this study uses a 1 (strongly disagree) $\sim 5$ (strongly agree) Likert scale in this study
} 